\title{
Beta-Glucans from Fungi: Biological and Health-Promoting Potential in the COVID-19 Pandemic Era
}

\author{
Iwona Mirończuk-Chodakowska *D, Karolina Kujawowicz and Anna Maria Witkowska (D)
}

check for updates

Citation: Mirończuk-Chodakowska, I.; Kujawowicz, K.; Witkowska, A.M. Beta-Glucans from Fungi: Biological and Health-Promoting Potential in the COVID-19 Pandemic Era. Nutrients 2021, 13, 3960. https:// doi.org/10.3390/nu13113960

Academic Editor: Jose M. Soriano

Received: 18 October 2021

Accepted: 4 November 2021

Published: 6 November 2021

Publisher's Note: MDPI stays neutral with regard to jurisdictional claims in published maps and institutional affiliations.

Copyright: (c) 2021 by the authors. Licensee MDPI, Basel, Switzerland. This article is an open access article distributed under the terms and conditions of the Creative Commons Attribution (CC BY) license (https:// creativecommons.org/licenses/by/ $4.0 /)$.
Department of Food Biotechnology, Faculty of Health Sciences, Medical University of Bialystok, Szpitalna 37, 15-295 Bialystok, Poland; karolina.kujawowicz@sd.umb.edu.pl (K.K.); anna.witkowska@umb.edu.pl (A.M.W.)

* Correspondence: iwona.mironczuk-chodakowska@umb.edu.pl; Tel.: +48-85-6865088; Fax: +48-85-6865089

\begin{abstract}
Beta-glucans comprise a group of polysaccharides of natural origin found in bacteria, algae, and plants, e.g., cereal seeds, as well as microfungi and macrofungi (mushrooms), which are characterized by diverse structures and functions. They are known for their metabolic and immunomodulatory properties, including anticancer, antibacterial, and antiviral. Recent reports suggest a potential of beta-glucans in the prevention and treatment of COVID-19. In contrast to $\beta$-glucans from other sources, $\beta$-glucans from mushrooms are characterized by $\beta$-1,3-glucans with short $\beta-1,6$-side chains. This structure is recognized by receptors located on the surface of immune cells; thus, mushroom $\beta$-glucans have specific immunomodulatory properties and gained BRM (biological response modifier) status. Moreover, mushroom beta-glucans also owe their properties to the formation of triple helix conformation, which is one of the key factors influencing the bioactivity of mushroom beta-glucans. This review summarizes the latest findings on biological and healthpromoting potential of mushroom beta-glucans for the treatment of civilization and viral diseases, with particular emphasis on COVID-19.
\end{abstract}

Keywords: $\beta$-glucans; macrofungi; mushrooms; food; SARS-CoV-2; COVID-19

\section{Introduction}

Mushrooms (macrofungi) have been a subject of interest to people for centuries. Edible mushrooms have been appreciated not only for their taste, but also for medicinal properties. The oldest data indicating the use of fungi by humans come from archaeological excavations dating back to about 8000 years BC. In the 1990s, two species of fungi were found by the corpse of an "ice man", namely, Piptoporus betulinus (Bull.) P. Karst, and the Fomes fomentarius (L.) Fr, which may have served "Ötzi", living 5000 years BC, as dressings or, presumably, they could have been treated as a cure for stomach problems. Another valued species with medicinal properties was Fomitopsis officinalis (Vill.) Bres used by the ancient Greeks and Romans as a cure for many diseases, such as excessive sweating during tuberculosis, dizziness, respiratory diseases, digestive problems, and even cancer. The therapeutic properties of fungi were earliest and most often used in the Far East, i.e., in China and Japan. In Europe, mushrooms were more frequently valued for their taste. The oldest text reports on the therapeutic properties of fungi date back to around the 1st century BC. They mention the Japanese shiitake (Lentinula edodes (Berk.) Pegler, Ganoderma lucidum (M.A. Curtis) P. Karst. Other species with documented medicinal properties in historical reports are Amanita muscaria (L.) Lam., used in the past to treat rheumatism and to restore the function of the secretory glands, and the Lycoperdon sp., used as an antihemorrhagic agent [1].

Apart from their nutritional value [2], mushrooms are attributed with a wide range of health-promoting properties [3-9]. They exhibit antioxidant [3], hypotensive [4], hypocholesterolemic [5], and hypoglycemic [6] as well as anticancer [7], immunomodulating [7], antiviral [8], and bacteriostatic properties [9]. The health properties of fungi result from the presence of biologically active substances, including phenolic compounds and vitamins (A, 
E, C), antioxidant elements, and amino acids [10-12]. In recent years, the greatest interest has been focused on beta-glucans, especially on the possibility of their use in the treatment of civilization diseases [13] and COVID-19 [14].

The aim of this review was to summarize the latest findings on biological and health promoting properties of mushroom beta-glucans with a potential to support the treatment of many disorders, including civilization and viral diseases, with particular emphasis on COVID-19.

\section{Review}

\subsection{Classification and Structure of Mushroom Glucans}

The most common polysaccharides in fungi are chitin, hemicellulose, beta-glucans, alpha-glucans, mannans, xylans, and galactans $[15,16]$.

Polysaccharides are a very diverse group of macromolecules whose monomers are linked by glycosidic bonds. Monomers in polysaccharides can be linked both linearly and form branched chains. The basic units forming the fungal polysaccharides may be glucose, fructose, glucuronic acid, arabinose, galactose, xylose, and mannose. Additionally, polysaccharides can be combined with peptides and proteins [17,18].

Fungal glucans can be linear or branched. The molecules of particular monosaccharides, mainly glucose, are connected by $\alpha$ - or $\beta$-glycosidic and also by the various types of different glycosidic linkages present in the same molecule. Mushroom D-glucans can have different linkage types, branching degrees, molecular weights, and solubility profiles $[19,20]$.

Heteropolysaccharides, among them, heteropolysaccharides with a homogeneous main chain (heterogalactans, heteroglucans, and heteromannans) and heteropolysaccharides with a heterogeneous main chain, are a more diverse group of biologically active polysaccharides [17]. Due to the structure of the basic chain of these compounds, they are divided into mannans, xylans, galactans, and fructans. The side chains of these macromolecules may include arabinose, fructose, mannose, galactose, or glucose [17,19,21-24]. Figure 1 shows the classification of fungal main polysaccharides.

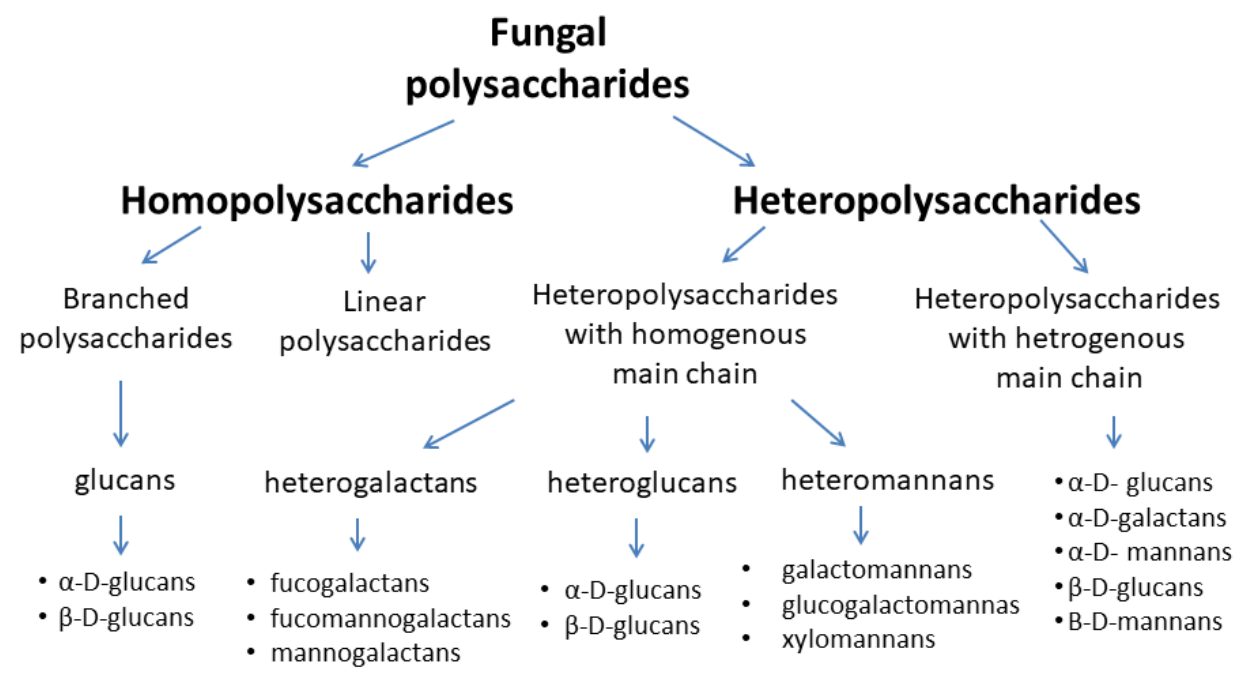

Figure 1. Classification of fungal polysaccharides [17,23,24].

\subsubsection{General Characteristic of $\beta$-Glucans}

Beta-glucans are polymers of $\beta$-D-glucose. They constitute part of cell walls of bacteria and plants, mainly algae and cereals, as well as microscopic fungi and macrofungi $[25,26]$. Beta-glucans have mainly a structure-forming role in the cell. They are divided into several different groups according to their structure, i.e., the degree of chain branching and the type of glycosidic bonds connecting the glucose monomers. $\beta$-1,3-glucans, without branches (linear), occur in bacteria. $\beta-1,3-1,4-\mathrm{D}$-glucans are mainly found in cereal grains such as

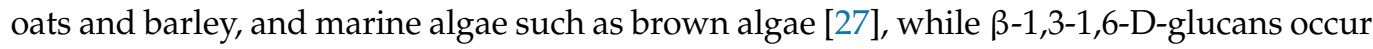


mainly in yeasts ( $\beta-1,3$-glucans with long-branched chains $\beta-1,6$ - (Sacharomyces cerevisiae)) and macrofungi ( $\beta-1,3$-glucans with short-branched chains $\beta-1,6-)$ [28].

Bioactivity of beta-glucans depends on the conformation of their molecules. Glucans, like other polymers, can adopt different chain conformations depending on the type of solvent, e.g., random coil, single helix, double helix, triple helix, worm-like, rod-like, and sphere-like shapes. However, beta-1,3-glucans with beta-1,6 branches or without branches make up a triple helix structure in its natural form and in aqueous solutions at room temperature. The triple helix structure determines the immunomodulatory and anticancer properties of beta-glucans [29].

$\beta$-glucans are essential components of cell walls in cereal grains, mainly oats, barley, rye, and millet. They occur in the outermost layer of grains (aleuronic layer) mainly as unbranched $\beta$-D-glucose chains linked by $\beta-1-3$ or $\beta-1-4$ glycosidic bonds. Their content, however, is quite low, ranging from $4-7 \%$. The highest molecular weights among cereal grain glucans are observed in $\beta$-glucans of oats $(3,000,000 \mathrm{Da})$ and barley $(2,100,000 \mathrm{Da})[30,31]$.

Cereal $\beta$-glucans show a number of health properties. They lower blood cholesterol and glucose [32], support the treatment of obesity, inflammation of the intestine, and gastric mucosa, and take part in the microbiota modulation $[5,32,33]$.

Beta-glucans are also a part of the inner layer of the yeast cell walls, where their content varies widely, ranging from $78 \%$ to $84 \%$ [33]. The content of glucans largely depends on the method of yeast cultivation. There are several types of glucans in the yeast cell wall, differing in the type of bonds and the branching of molecules. Among others, there are high-molecular-weight, insoluble 1-3- $\beta$-glucans with a few side branches connected to the main chain by a $\beta-1-6$ bond, low-molecular-weight, highly branched $\beta-1-6$-glucans with side branches connected to the main chain by a $\beta-1-3$ bond, and low-molecular-weight, soluble $1-3-\beta$-glucans with side chains connected by a $\beta-1-6$ bond $[33,34]$.

\subsubsection{Mushroom Beta-Glucans}

The beta-glucan content of macrofungi depends on the species, environment, and maturity of the fruiting body, ranging between $3.1 \%$ and $46.5 \%[25,35,36]$.

Mushroom polysaccharides contain various types of glycosidic bonds and, thus, are grouped as beta-glucans, alpha-glucans, and heteroglycans. Beta-glucan molecules in individual species of fungi differ in the structure of the base chain and the number and type of bonds, as well as the type and number of side chain branches and structure (e.g., triple helix, single helix, or random helix) and in molecular weight [37]. Macrofungal beta-glucans are considered natural biological response modifiers (BRMs) [38]. Table 1 shows examples of the best-studied beta-glucans.

Table 1. Examples of studied beta-glucans of macrofungi.

\begin{tabular}{|c|c|c|c|c|}
\hline Name of $\beta$-Glucan & Abbreviation & Mushroom Species & Glucan Structure & Reference \\
\hline Krestin & $\begin{array}{l}\text { PSK } \\
\text { PSP }\end{array}$ & Trametes versicolor & $\begin{array}{c}1,3-\beta \text {-glucan } \\
1,4-\beta \text {-glucan } \\
\text { multi-sugar-protein complex containing } \\
\text { mainly } 1,3-\beta \text {-D-glucans }\end{array}$ & {$[39,40]$} \\
\hline Tylopilan & - & Tylopillus felleus (Bull.) & $1,3-1,6-\beta$-glucan & [41] \\
\hline Lentinan & LNT & Lentinula edodes & $1,3-1,6-\beta$-glucan & [42] \\
\hline Pleuran & - & Pleurotus ostreatus & $1,3-\beta$ - glucan with galactose and mannose & [43] \\
\hline Schizophyllan & SPG & Schizophyllum commune & $1,3-1,6-\beta$-glucan & [44] \\
\hline MD-fraction & PDF & & $1,6-1,3-\beta$-glucan & [45] \\
\hline Grifolan & GRN & Grifola frondosa & $1,3-1,6-\beta$-glucan & {$[46]$} \\
\hline Scleroglucan & SSG & $\begin{array}{l}\text { Sclerotium glucanicum } \\
\text { Sclerotium rolfsii }\end{array}$ & $1,3-1,6-\beta$-glucan & [47] \\
\hline
\end{tabular}




\subsection{Structural Characteristics of Selected Beta-Glucans from Macrofungi}

\subsubsection{Lentinan}

Lentinan is a part of cell walls of Lentinula edodes (shiitake), which was first isolated in 1970 by Chihara et al. [48]. This is 1,3-1,6- $\beta$-glucan, whose basic unit is a five-molecule glucose core with two glucose side chains (one for every three glucose molecules in the basic chain) attached to the main chain by $\beta-1,6$-glycosidic bonds (Figure 2). Lentinan forms a triple helix chain in aqueous solutions. Its molecular weight varies from 300 to $800 \mathrm{kDa}$, with the average of about $500 \mathrm{kDa}$ (Daltons). Lentinan primarily possesses an immune enhancement effect in tumor patients, as well as the immunomodulatory properties $[49,50]$. Polysaccharides extracted from L. edodes have not only the enhancement effect, but may also inhibit tumor growth through various mechanisms, such as inducing tumor cell apoptosis and directly killing tumor cells [51,52]. Lentinan is considered to be one of the most active components in mushrooms (L. edodes). It attracts many researchers due to its low toxicity and many medicinal and pharmacological properties. In addition to its immunostimulatory and anticancer properties, lentinan demonstrates antioxidant and blood lipid-lowering effects $[53,54]$. The latest research suggests that dietary supplementation of beta-glucans isolated from L. edodes may be an effective nutritional support to prevent obesity-associated cognitive decline [55].

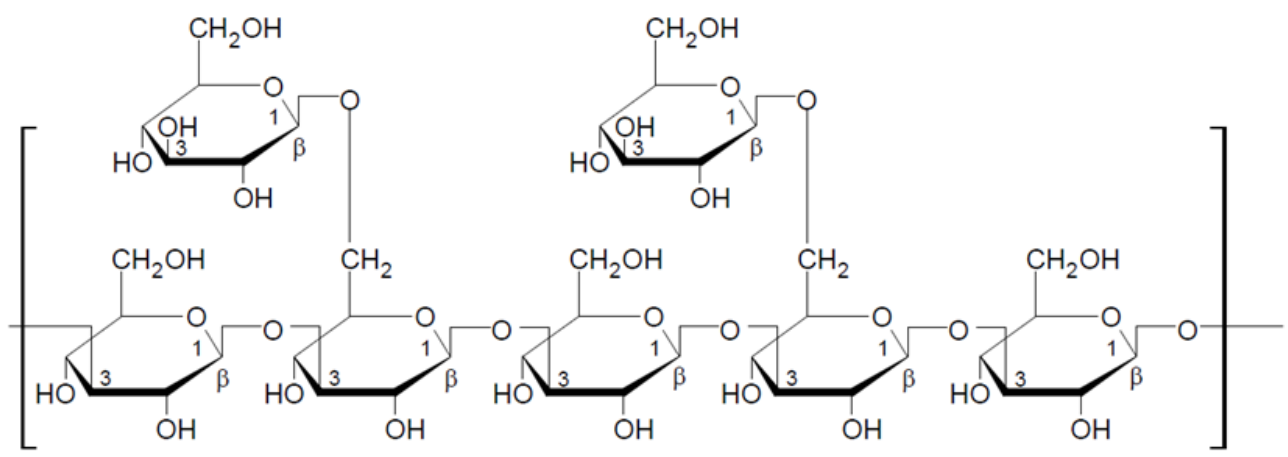

Figure 2. Chemical structure of lentinan [42].

\subsubsection{Schizophyllan}

Schizophyllan is a beta-glucan isolated from the mushroom Schizophyllum commune. Schizophyllan was first isolated by Kikumoto et al. in 1970 [56]. The monomeric unit of this polysaccharide consists of three glucose molecules linked by $\beta-1-3$-glycosidic bonds with one glucose side chain linked to the basic chain by a $\beta-1-6$-glycosidic bond (Figure 3 ). The molecular weight of schizophyllan is $100-200 \mathrm{kDa}$. As lentinan, schizophyllan forms a triple helix in aqueous solutions $[44,57,58]$. The properties of schizophyllan depend on several factors, including the monosaccharide composition, molecular weight, and water solubility; the extraction methods strongly influence these physicochemical properties [58].

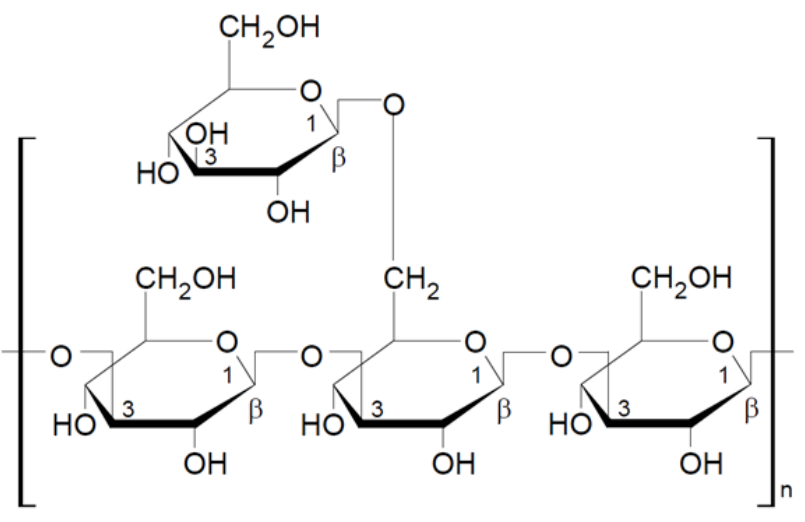

Figure 3. Chemical structure of schizophyllan [44]. 
Recent studies have shown that schizophyllan enhances the anti-inflammatory response in mouse macrophages, which may be useful in the formation of inferences during inflammatory diseases such as periodontal disease [59]. Schizophyllan has the ability to activate the dectin-1 receptor, which contributes to the increased secretion of pro-inflammatory cytokines, but at the same time strongly promotes the production of IL-10, a key antiinflammatory cytokine that plays an important role in controlling inflammation [59].

\subsubsection{Krestin}

Krestin (PSK), $\beta$-glucan of arboreal fungus, is extracted from Trametes versicolor (L.) Lloyd. It is a protein-bound beta-glucan classified as a heteroglycan [40]. The chemical structure of the polysaccharide chain is shown in Figure 4. The molecular weight of krestin is 100,000 Da on average. Krestin, like lentinan, is a popular drug in Japan. Numerous clinical trials confirm its positive effect on the condition of patients undergoing chemotherapy due to breast, liver, stomach, colon, lung, and prostate cancer [60]. The antitumor activity of PSK lies in its ability to stimulate T lymphocytes and antigenpresenting cells, which enables proper recognition and destruction of neoplastic cells $[60,61]$. Krestin also shows immune-boosting and antiviral properties and hypocholesterolemic and prebiotic activity [40,62].

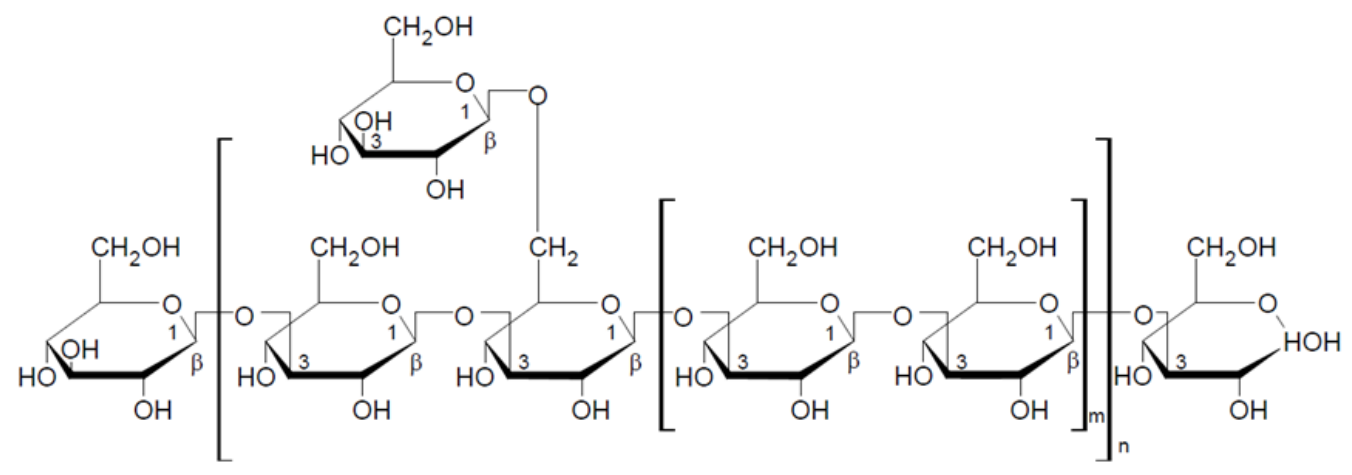

Figure 4. Chemical structure of the krestin repeat unit [63].

\subsubsection{Grifolan}

Grifolan is a 1,3-1,6- $\beta$-D-glucan isolated from the edible mushroom Grifola frondosa (Dicks.) Gray. The molecular weight of this polysaccharide is about 1,000,000 Da. The monomer of grifolan molecule is built from three glucose units in the main chain and one side chain attached to the main chain by $\beta-1,6-$ glycosidic bond (Figure 5). Grifolan has proven antitumor properties when administered orally, demonstrated by in vivo anti-tumor testing and in mouse tumor models [64,65]. It is one of the most effective beta-glucans that can be used in supporting the treatment of diabetes. One study found that the oral administration of submerged-culture mycelia and broth of Grifola frondosa improved hyperglycemia and diabetes-induced alterations in cell-mediated and innate immunities in T2DM rats [66].

\subsubsection{Pleuran}

Pleuran is 1,3-1,6- $\beta$-glucan extracted from Pleurotus ostreatus and sold as a dietary supplement under the commercial name Immunoglukan. The basic unit of this polysaccharide consists of four glucose molecules connected by $\beta-1-3$-glycosidic bonds, and every fourth glucose unit is linked by a side chain with a $\beta-1-6-$ glycosidic bond (Figure 6). The molecular weight of pleuran is between 600,000 and 700,000 Da [49]. 


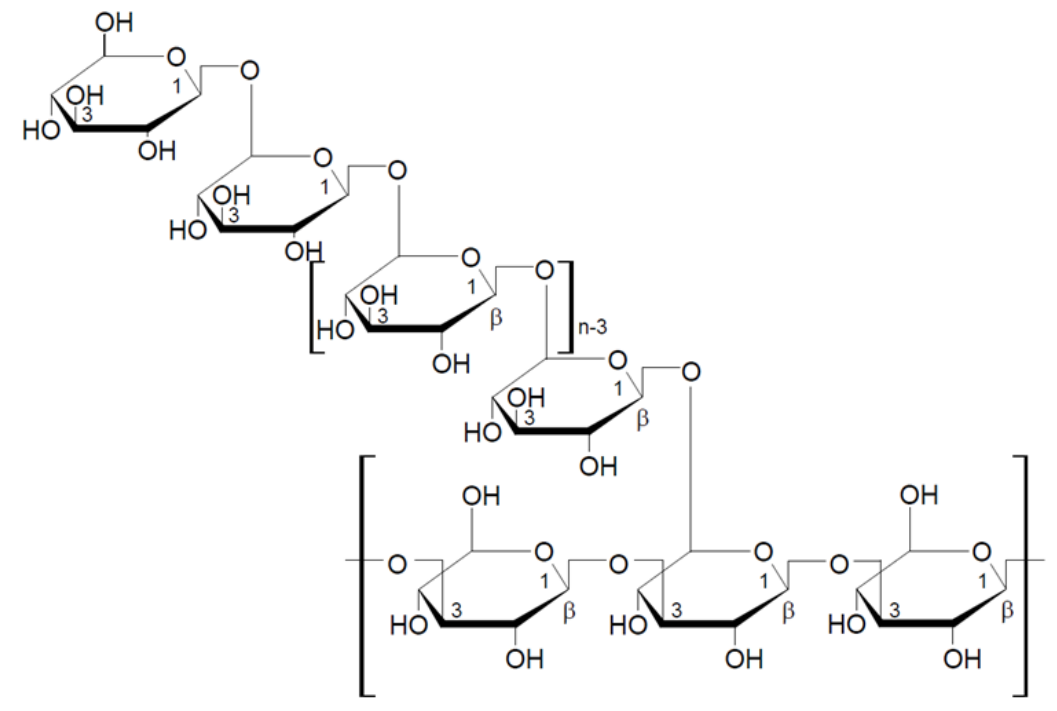

Figure 5. Chemical structure of the grifolan repeat unit [67].

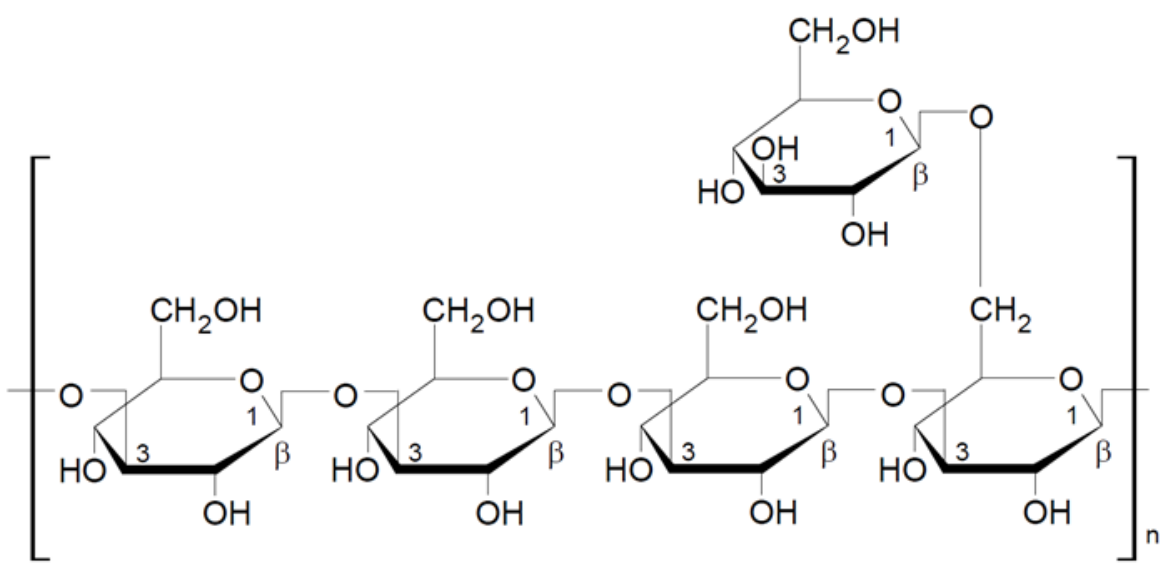

Figure 6. Chemical structure of the pleuran repeat unit [49].

Pleuran's healing properties and the ability to rebuild the epithelium have been scientifically proven in infections of the respiratory system [68,69]. It has been also found to have anti-viral properties against HSV (Herpes Simplex Virus) [70].

\subsection{Mechanisms of Action of Beta-Glucans in the Human Body}

Biological activity of fungal polysaccharides may vary depending on the type of structural monomers, the size of the molecule, the degree of its branching, and solubility in water, as well as on the structure that beta-glucans adopt in the presence of water. Studies show that high-molecular-weight molecules with $\beta$-1-3-bonds in the base chain have the best anticancer properties [71,72].

Most $\beta-1,3$-glucans show resistance to gastric juice. In an unchanged form, they pass into the small intestine, where they bind to macrophage receptors (dectin-1) in the intestinal wall and are then transported to the spleen, lymph nodes, and bone marrow. In macrophages, high-molecular-weight $\beta$-glucans are degraded into smaller fragments, which are then bound by complement receptors 3 (CR3) found on immune cells, including granulocytes. Thus, the immune response directed against tumor cells is stimulated [73].

A large diversity in the structure of the beta-glucan chain affects their diverse biological activity. Previous scientific reports attributed immunomodulatory, anticarcinogenic, hypolipemic, hypoglycemic, and protective effects on the circulatory system to beta-glucans. However, most of the properties of mushroom beta-glucans are due to their effects on 
the host immune system $[74,75]$. Figure 7 shows selected functions of beta-glucans in the human body.

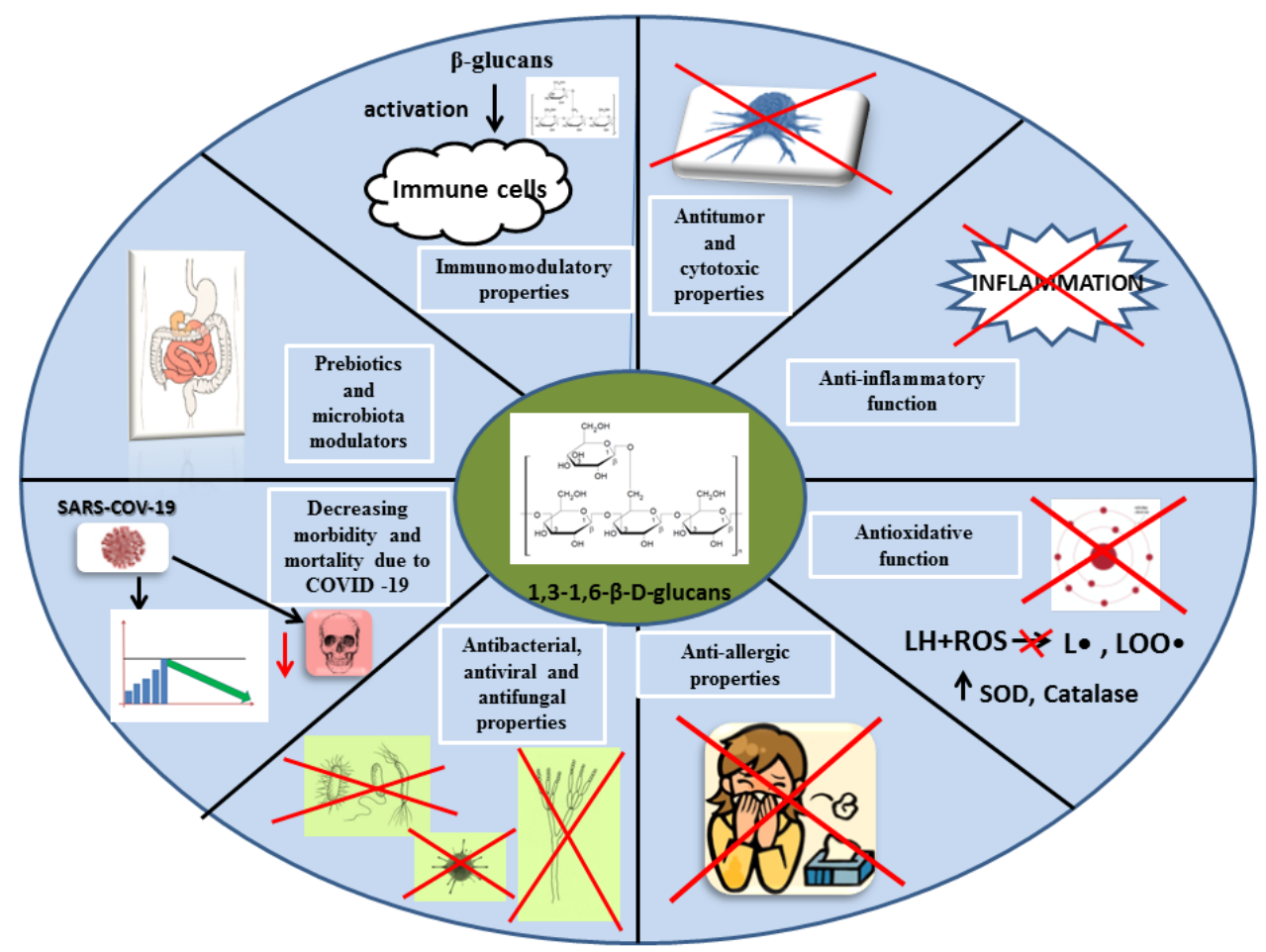

Figure 7. Biological activities of beta-glucans in the human body. SOD, superoxide dismu-

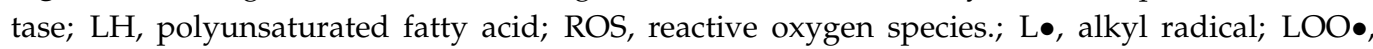
superoxide radical.

\subsubsection{Immunomodulatory Properties of Beta-Glucans}

Among all the mushroom-derived beta-glucans tested, most showed immunomodulatory activity. The effect on the immune system is based on the ability of beta-glucans to bind to receptors such as dectin-1, toll-like receptors (TLRs), complement receptors type 3 (CR3), scavenger receptors (Src), and lactosylceramide receptors (LacCer) present on immune cells [76].

Dectin- 1 is the most abundant receptor present on dendritic cells, monocytes, macrophages, neutrophils, and T lymphocytes. The activation of dectin-1 leads to the stimulation of phagocytosis, endocytosis, and the production of reactive oxygen species (ROS) directed against pathogenic microorganisms [77]. Dectin-1 also stimulates the production of cytokines (TNF- $\alpha$, IL-2, IL-10, IL-12) [78].

TLRs (toll-like receptors) are very important receptors of the immune system. They are essential in the early stages of infection to initiate an effective innate immune response. At a later stage of infection, they regulate the adaptive immune response [79]. Beta-glucan molecules, after binding to TLR 2 or TLR 4, activate the innate immune response [80]. The stimulated TLR 2 via nuclear factor NF- $\kappa B$ induces the production of cytokines, among them, TNF- $\alpha$ and IL-12 [81,82].

Complement Receptor Type 3 (CR3) is found mainly on neutrophils, monocytes, and NK cells (natural killers), but not on macrophages [81,83]. Attachment of $\beta$-glucans to CR3 increases leukocyte adhesion to microbial cells and activates the cytotoxicity pathway directed against tumor cells [81,84,85].

Src receptors (Scavenger receptors) are located primarily on endothelial cells [86]. Receptors stimulated by beta-glucans, e.g., lentinan, trigger the activation of a number of signaling pathways in the human immune system [87]. Among others, they are responsible for the activation of mitogen-activated kinases (MAPK), phosphatidylinositol kinase (PI3K), and endothelial nitric oxide synthase (eNOS) [88]. 
Lactosylceramide (LacCer) receptors are located on neutrophils and endothelial cells. The receptors on endothelial cells, stimulated by $1,3-\beta$-glucans, contribute to the activation of NF- $\mathrm{KB}$ and the synthesis of macrophage inflammatory protein (MIP-2) and TNF- $\alpha$ [89]. Stimulated receptors on neutrophils cause increased ROS production necessary to inactivate pathogenic microorganisms through activation of the MAPK and PI3K cascades [90].

Figure 8 shows the possible $\beta$-glucan immunomodulatory mechanism of action in the human body.

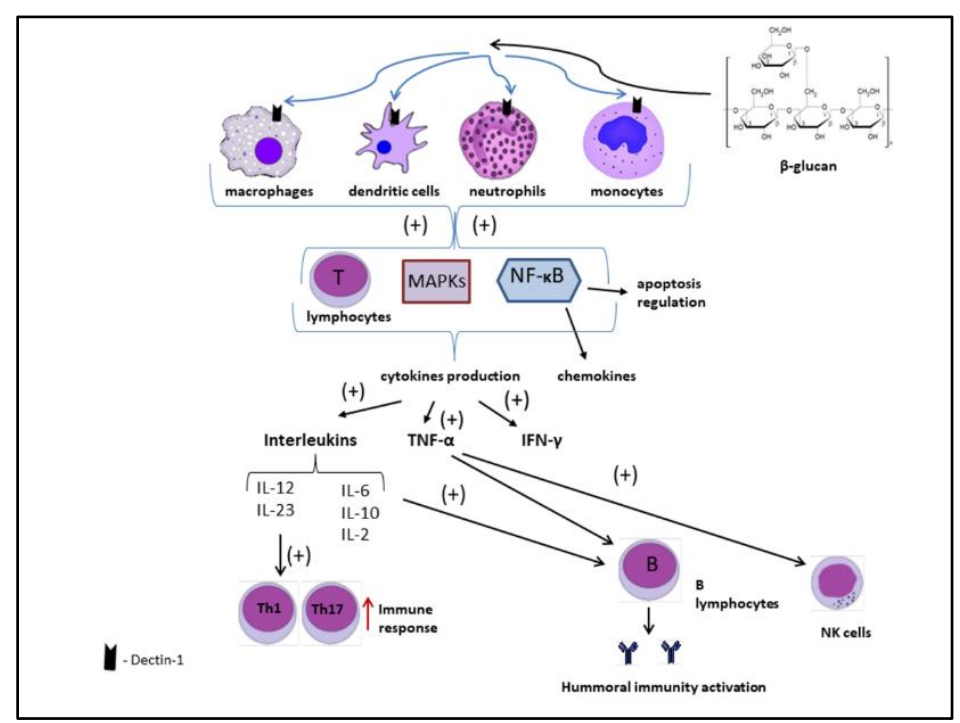

Figure 8. Mechanism of immunomodulatory action of beta-glucans. Authors' elaboration based on $[6,8,91]$.

Beta-glucans bind to dectin-1 receptors located on macrophages, dendritic cells, neutrophils, and monocytes. This combination results in the activation of many compounds responsible for the immune response, including, among others, nuclear factor kappa-B (NF$\kappa B)$. When NF- $k B$ is activated, it imports to nucleus and binds specific DNA sites. In the signaling pathway, NF- $\mathrm{KB}$ is downstream of mitogen-activated protein kinases (MAPKs). Additionally, T lymphocytes are stimulated. Chemokines and cytokines, including interleukins, interferon- $\gamma(\mathrm{IFN}-\gamma)$, and tumor necrosis factor alpha (TNF- $\alpha)$, are released. As a result, the cellular and humoral response of the immune system is enhanced $[6,8,91]$.

Beta-glucans derived from Pleurotus are attributed with the strongest immunomodulatory properties, which include stimulation of phagocytosis directed against pathogenic microorganisms [92,93].

\subsubsection{Antitumor and Cytotoxic Properties of Beta-Glucans}

The mechanisms involved in the anticancer effects of beta-glucans are not fully understood. Until recently, it was believed that beta-glucans do not possess cytotoxic properties directed against cancer cells and do not trigger apoptotic activity [37]. So far, the described mechanisms of anti-cancer action of beta-glucans have been based on their indirect action through activity towards cells of the immune system [94]. However, scientific reports indicate the cytotoxic activity of beta-glucans isolated from Agaricus bisporus and the Lactarius rufus, directed against liver cancer cells (HepG2) [95].

Currently, the most well-known polysaccharides with anticancer activity are lentinan, schizophyllan, and krestin, which are proposed as complementary therapy for cancer treatment, especially in Japan [37,96-99].

The anticancer mechanism of beta-glucans shows synergistic effects with monoclonal antibodies used in cancer therapy [81,100]. Apart from those described above, the anticancer function of polysaccharides has been observed in many types of mushrooms, including Agaricus, Ganoderma, Pleurotus, and Lentinus. The anticancer properties of 
polysaccharides have been proven for colorectal [101-103], lung [104], gastric [37,105], and cervical cancers $[106,107]$.

The increasing number of cancer cases contributes to the search for substances with anti-cancer effects. Bioactive substances of natural origin, which are safer and cheaper than drugs commonly used in chemotherapy, are receiving increasing attention in the scientific community. Extensive research on polysaccharides of fungal origin has been going on for several decades. Several of them have already been officially registered as drugs [108-110].

\subsubsection{Anti-Inflammatory Function of Beta-Glucans}

The best-studied fungal polysaccharides with anti-inflammatory properties are heteroglycans ( $\beta$-D-glucans with side chains of xylose, mannose, galactose, and glucuronic acid) [111-113].

Oral administration of beta-glucans isolated from fungi produced similar effects in animal models to those of non-steroidal anti-inflammatory drugs and glucocorticoids. Therefore, one of the suggested mechanisms of anti-inflammatory action of beta-glucans is inhibition of the production of pro-inflammatory cytokines (e.g., interleukin 1 $\beta$ ) [114]. Another mechanism suggested for the anti-inflammatory properties of beta-glucans is their ability to inhibit the enzymes cyclooxygenase- 2 and nitric oxide synthase [115]. The antiinflammatory function of beta-glucans is also important in the prevention and treatment of neurodegenerative diseases such as Parkinson disease and Alzheimer disease [116]. The abovementioned polysaccharides with anti-inflammatory properties have been isolated from Agaricus blazei and Lactarius rufus, among others [113,117].

\subsubsection{Antioxidant Properties of Beta-Glucans}

Pleurotus mushrooms are considered to be one of the most valuable mushrooms in terms of health. They are an excellent source of numerous bioactive compounds including polysaccharides. Beta-glucans isolated from fungi of the genus Pleurotus possess numerous therapeutic properties, including antioxidant effects $[118,119]$. Mannogalactoglucan isolated from the species Pleurotus sajor-caju exhibits free radical scavenging, reducing and chelating properties towards iron ions [120]. Antioxidant properties of polysaccharides of fungal origin were also observed in two polysaccharide fractions, PSPO-1a and PSPO-4a $[119,121]$. Polysaccharides isolated from Pleurotus ostreatus show strong reducing properties against the 2,2-diphenyl-1-picrylhydrazyl (DPPH) radical and the superoxide anion radical [119]. Polysaccharides isolated from Armillaria mellea exhibit antioxidant properties based on their ability to reduce the DPPH radical, chelate transition metals, and have strong reducing properties [122]. Polysaccharides isolated from Trametes versicolor, Agaricus spp., and L. edodes show significant antioxidant properties [123-125]. They have chelating properties that reduce lipid oxidation. Polysaccharide extracts from G. lucidum, Ganoderma tsugae, and Polyporus dermoporus have the ability to scavenge free radicals as well as to counteract a respiratory burst leading to ROS formation [126-128]. Polysaccharides from Morchella esculenta in laboratory mice showed potent antioxidant activity directed against the most potent oxidant in living organisms, the hydroxyl radical [129]. The polysaccharide significantly reduced the production of malondialdehyde (an indicator of the lipid peroxidation process) in serum and liver cells of laboratory animals [129].

It is worth nothing that mushroom-derived polysaccharide molecules exhibit greater antioxidant activity than monosaccharides because the polymeric chains have a greater ability to extract anomeric hydrogen and to inactivate free radicals [130].

\subsubsection{Beta-Glucans in the Treatment of Allergies}

Currently, a large increase in allergic diseases is observed among populations worldwide. None of the civilization diseases show such a growth rate. Allergy is called an abnormal, excessive reaction of the immune system to various substances present in the environment, which we call allergens. Based on the route of entry of the allergen 
into the body, allergies are divided into inhalation, food, contact, venom reaction, and drug reaction $[131,132]$.

Numerous in vitro, laboratory animal, and clinical studies indicate the anti-allergic function of beta-glucans [133-135]. The anti-allergic properties of beta-glucans are mainly attributed to 1,3-1,6- $\beta$-glucans found in fungi. A study involving the administration of beta-glucans to laboratory mice with asthma confirmed the healing effect of beta-glucans, which was similar to treatment with dexamethasone [136]. Moreover, one study carried out among children with recurrent respiratory infections confirmed the significant antiallergic function of pleuran [137]. After 6 months of administration of this polysaccharide at $10 \mathrm{mg} / \mathrm{kg}$, a significant reduction in peripheral eosinophilia and stabilization of total class E immunoglobulin (IgE) was observed [137]. In the study by Sarinho et al. [138], the administration of mushroom-derived beta-glucans to patients with asthma resulted in an increased production of the anti-inflammatory interleukin 10 (IL-10). A Japanese clinical trial involving oral administration of lentinan to allergy patients also confirmed a reduction in serum levels of immunoglobulin class E (IgE) [139].

The majority of studies conducted so far have confirmed that oral administration of polysaccharides, mainly beta-glucans isolated from Basidiomycetes, may prevent allergies by decreasing the level of immunoglobulin class $\mathrm{E}(\mathrm{IgE})$ and increasing the production of IFN- $\gamma$ (interferon-gamma) [134,140,141].

\subsubsection{Antibacterial, Antiviral, and Antifungal Properties of Mushroom Beta-Glucans}

There are a number of compounds in mushrooms that can inhibit the growth of microorganisms in humans. Numerous natural antibiotics and antiviral substances have been isolated from mushroom fruiting bodies, including triterpenes, ganodermadiol, ganodermic acid, and lucidol, showing activity against herpes virus, influenza, and HIV [142-144]. Polysaccharides, mainly $\beta$-glucans, are also responsible for their microbial inhibitory properties $[145,146]$. The mechanism of action of glucans against microorganisms mainly involves the activation of several different immunomodulatory mechanisms, including phagocytosis, in which the phagocytic cells of the immune system, neutrophils, and macrophages participate [134,147].

The first studies on the antimicrobial activity of beta-glucans were conducted in the 1980 s using yeast $\beta$-glucans [147]. They found the protective effect of $\beta$-glucans against infections caused by Staphylococcus aureus $[147,148]$. An inhibitory effect of lentinan on the development of tuberculosis was observed through stimulation of macrophages [149]. In the animal studies, the addition of beta-glucans to the food of various fish species resulted in an increase in their resistance to pathogenic bacteria of the Aeromonas and Vibrio genera [150,151]. A number of studies described the great antiviral potential of beta-glucans [152-155]. The first experiments on the antiviral activity of $\beta$-glucans were performed on tobacco plants, and antiviral effects were observed with lentinan, schizophyllan, and zymosan $[156,157]$. In the 1990s, a positive treatment effect was observed in HIV patients, when lentinan was administered together with the antiretroviral drug didanosine [153]. A significant increase in the percentage of helper T lymphocytes (Th) was observed, greater than when the drug was administered alone [153]. Similar results were obtained by US researchers 16 years later [154]. Studies showed that lentinan also exhibits inhibitory effects on the replication of the herpes simplex virus (HSV), mumps, polio, measles, and viral encephalitis virus [158]. The evidence shows that $\beta$-glucans can reduce the incidence of lower respiratory tract infections and decrease the frequency of the flu-like diseases in children [68].

An inhibitory effect of polysaccharides isolated from Auricularia auricula-judae on Newcastle disease virus (NDV) was observed in Chinese studies conducted on chicken embryos [159]. Dietary lentinan supplementation maintained normal function of piglets even when they were infected with rotavirus, as reflected by reduced growth, performance loss, and diarrhea prevalence, and maintained gut immunity [160]. 
Currently, opportunistic microscopic fungal infections are very common due to the widely used antibiotic therapy. Candidiasis is particularly dangerous in immunocompromised patients, e.g., HIV-infected or cancer patients. It has been proven that edible mushrooms, due to the presence of numerous bioactive compounds, such as agrocybin, ganodermine, pleurostrin, or eryngin, inhibit the growth of microscopic fungi of the genera Fusarium, Mycosphaerella, and Physalospora [152,161-163].

Beta-glucans of macrofungi also play an important role in the protection against mycoses. The dectin-1 receptor present on immune cells plays a significant role in their activity. It has the ability to bind to certain $\beta$-glucans. Thus, $\beta$-glucans of edible mushrooms stimulate cell phagocytosis, increasing the non-specific cellular response of the host immune system directed against pathogens [164]. Another receptor, toll-like receptors (TRL) located on phagocytic cells, plays an important role in controlling fungal infections $[165,166]$.

\subsubsection{Potential Role for Beta-Glucans in Decreasing Morbidity and Mortality Due to COVID-19}

Since December 2019, coronavirus disease 2019 (COVID-19) caused by the severe acute respiratory syndrome corona virus 2 (SARS-CoV-2) has rapidly spread all over the world. A significant proportion of patients infected with SARS-CoV-2 develops a mildly symptomatic infection, but also a large part of patients experiences serious complications including acute respiratory distress syndrome (ARDS). ARDS is characterized by extensive inflammation of the lungs, which requires intensive care [167].

COVID-19 infections are characterized by pro-inflammatory status, with high levels of different cytokines, including (IL)-1 $\beta$, IL-1R $\alpha$, IL-2, and IL-10. Critically ill patients requiring a stay in the intensive care unit were characterized by noticeably high concentrations of IL-2, IL-10, G-CSF, IP10, MCP1, MIP1A, TNF $\alpha$, and IL-6 [168]. Uncontrolled production of proinflammatory interleukins and cytokines that cause inflammatory or cytokine storm (CS) in the lungs is induced by the binding of SARS-CoV-2 virus to the Toll-Like receptors (TLR) $[169,170]$. A high increase in proinflammatory factors such as IL-6, IL-8, IL-1 $\beta$, and GM-CSF and chemokines such as CC12, CCL-5, IP-10, and CCL3, along with reactive oxygen species in patients with COVID-19, is closely correlated with ARDS, leading to pulmonary fibrosis and death [168]. All changes in cytokine levels are related to various changes in cellular ingredients of the immune response, which shows close association between infection with COVID-19 and individual response from the immune system, resulting in different clinical symptoms [170].

Zhang et al. showed that anti-inflammatory therapy (suppression of pro-inflammatory interleukins, such as IL-1 and IL-6) can have a therapeutic effect in inflammatory diseases including viral infections [167]. This study found that the course of infection caused by the SARS-CoV-2 virus largely depends on the functioning of the individual immune system [167]. The innate immune system plays a crucial role in the early recognition of infecting pathogens and activation of a pro-inflammatory response, which is the first line of defense in various infections [170]. Recent studies have shown that the innate immune system may possess some form of memory called Trained Immunity (TRIM) [171]. Cells of the innate immune system stimulated with some factors, e.g., BCG vaccine (Bacillus Calmette-Guérin vaccine) or beta-glucans, go through metabolic, mitochondrial, and epigenetic reprogramming, with an outcome in a memory phenotype of an enhanced immune responses [172]. Beta-glucans can stimulate the immune responses and can act as a training agent, which leads to increased immune response when these trained cells are exposed to a secondary stimulus in the form of pathogens [172]. It was shown that $\beta$-glucans used as the training factor demonstrate protective activity against secondary fungal, bacterial, or viral infections [173,174].

Figure 9 shows a possible mechanism of action of beta-glucans during infection with SARS-CoV-2. 


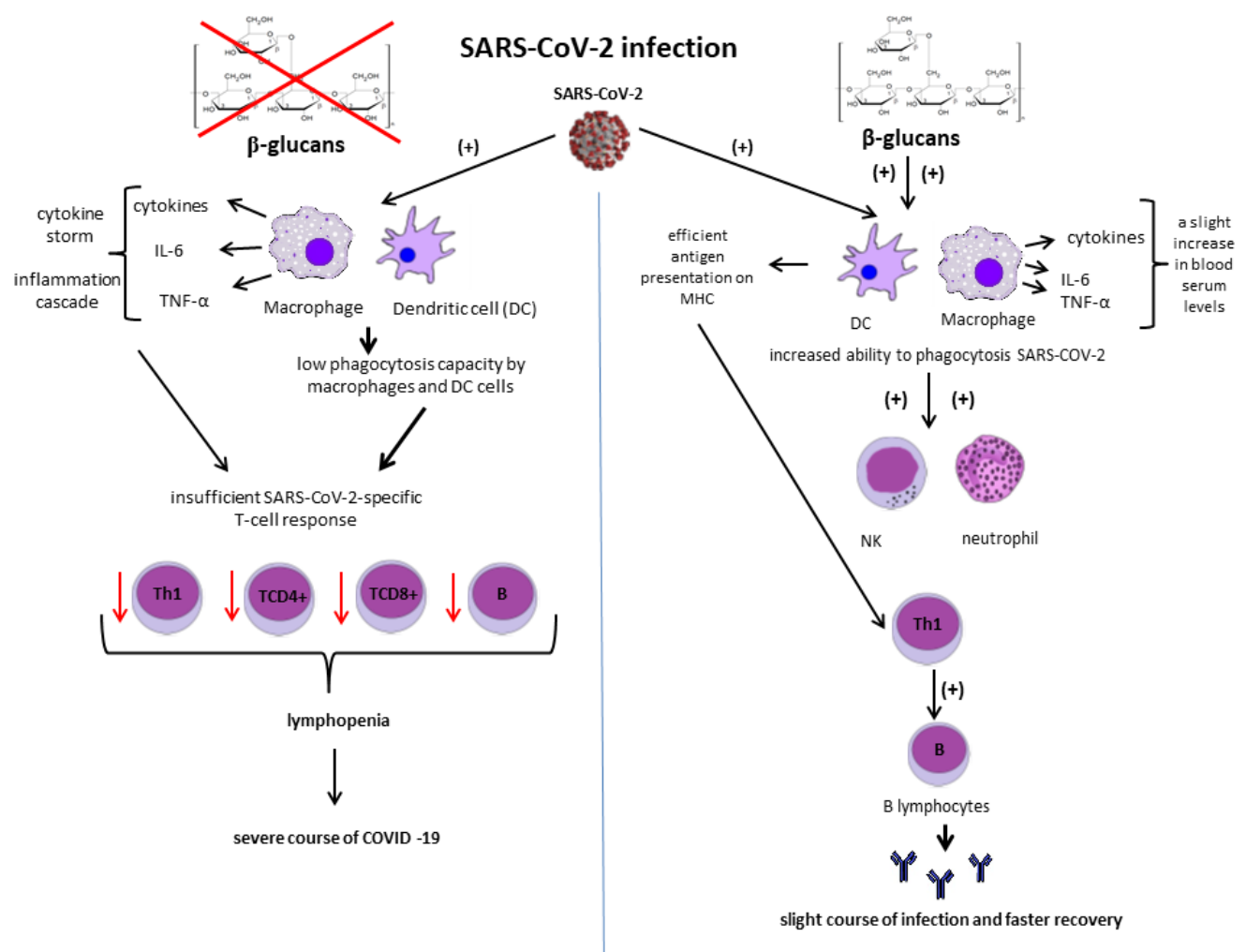

Figure 9. Possible mechanism of action of beta-glucans during SARS-CoV-2 infection. Authors' elaboration based on [172,175].

$\beta$-glucans activate macrophages and DC (Dendritic Cells) via appropriate receptors (Dectin-1, TLR, CR3). This results in an enhanced ability to phagocytose and efficiently present antigen on the MHC. Furthermore, $\beta$-glucan-induced macrophages can induce an enhanced defensive response of neutrophils and NK cells. Beta-glucan-induced DC cells present the virus more efficiently to $T$ lymphocytes, which promotes stimulation of $B$ lymphocytes and antibody production. Thus, beta-glucans may favorably influence the development of a long-term, specific, adaptive response to SARS-CoV-2 [172,175].

Geller and Yan [172] hypothesized that the use of oral administration of beta-glucan in a prophylactic setting could be an effective way to boost immune response and abrogate symptoms of COVID-19. Beta-glucans as TRIM inducers probably cause increased phagocytic capacity of macrophages and dendritic cells, which results in better processing and presentation of viral units to MHCs [84]. The 1,3-1,6-beta-glucans are considered to be the best biological response modifiers and have immunogenic properties [176]. Most glucans with this chain structure are derived from macrofungi (mushrooms) or yeast $[172,177]$. The hypothesis posed by Galler and Yan [172] was corroborated by other authors, who found that $\beta$-glucans from mushrooms demonstrated the potential for the treatment of lung injury [178]. In an in vitro study, L. edodes was shown to have potential for the treatment of COVID-19 due to its content of beta-glucans, which, through its effect on the immune system, reduces cytokine storm and, thus, ARDS [14]. This study demonstrated reduced inflammation in a lung epithelial model depending on the dose [14].

Another beneficial implication of the use of beta-glucans among people suffering from COVID-19 may be a decrease in the systolic and diastolic blood pressure [172]. In recent years, several studies have been published on the use of glucans in the prevention and treatment of viral diseases, especially in the context of COVID-19 (Table 2). Because of the few scientific reports to date on the function of mushrooms, beta-glucans in COVID-19 disease studies on both macrofungi and yeast are included in Table 2 for comparison purposes, as well as to highlight the high therapeutic potential of total fungal glucans in the prevention and treatment of COVID-19. 
Table 2. Potential of yeast and mushroom glucans for the prevention, course, and complications of COVID-19.

\begin{tabular}{|c|c|c|c|}
\hline No. & Type of Glucan & $\begin{array}{l}\text { Mechanism of Action in Prevention and Treatment } \\
\text { of COVID-19 }\end{array}$ & References \\
\hline 1. & $\begin{array}{c}\text { AFO-202- } \beta \text {-glucan } \\
(\beta-1,3-1,6 \text { glucan from black yeast } \\
\text { Aureobasidium pullulans })\end{array}$ & $\begin{array}{l}\text { Potential as a vaccine adjuvant against COVID-19; } \\
\text { Prevention of COVID-19-associated coagulopathy. }\end{array}$ & [179] \\
\hline 2. & $\begin{array}{c}\text { AFO-202 }-\beta \text {-glucans } \\
(\beta-1,3-1,6 \text { glucan from black yeast } \\
\text { Aureobasidium pullulans })\end{array}$ & $\begin{array}{c}\text { Regulation of blood glucose and lipid levels by } \\
\beta \text {-Glucans as an indispensable tool of defense } \\
\text { against COVID-19. }\end{array}$ & {$[180,181]$} \\
\hline 3. & $\begin{array}{c}\text { AFO-202- } \beta \text {-glucan } \\
(\beta-1,3-1,6 \text { glucan from black yeast } \\
\text { Aureobasidium pullulans })\end{array}$ & $\begin{array}{c}\text { Immune enhancement by } \\
\text { decreasing hyper-inflammation factors (IL-6) and } \\
\text { minimizing the likelihood of a cytokine storm; } \\
\text { increasing IFN- } \gamma \text {, sFAS, and factors like IL-7; } \\
\text { and enhancing anti-viral cytotoxic immunity, (T cells, } \\
\text { NK cells, macrophages, antibody production by } \\
\text { B cells). }\end{array}$ & [168] \\
\hline 4. & $\begin{array}{c}\text { AFO-202- } \beta \text {-glucan } \\
(\beta-1,3-1,6 \text { glucan from black yeast } \\
\text { Aureobasidium pullulans })\end{array}$ & $\begin{array}{l}\text { Immune regulatory and enhancing immune system; } \\
\text { Immune stimulator that can activate macrophages and } \\
\text { have positive immune actions on B-lymphocytes, } \\
\text { natural killer cells, and suppressor T cells in the } \\
\text { immune system. }\end{array}$ & {$[168,182]$} \\
\hline
\end{tabular}

5. 1,3- $\beta$-D-glucan (from Saccharomyces cerevisiae)

Prevention and treatment of excessive microglia activation during chronic inflammation characteristic of COVID-19 course.

\begin{tabular}{|c|c|c|c|}
\hline 6. & $\begin{array}{l}\text { 1,3- } \beta \text {-D-glucan } \\
\text { (curdlan and fragmentated zymozan- } \\
\text { proteoglucan from Saccharomyces cerevisiae) }\end{array}$ & $\begin{array}{l}\text { Potentials to enhance microglial function and } \\
\text { regeneration of CNS axons in } \\
\text { COVID-19 neurological sequalae. }\end{array}$ & {$[184,185]$} \\
\hline 7. & $\begin{array}{c}1,3-1,6-\beta-\mathrm{D} \text { glucans } \\
\text { (from shiitake mushroom Lentinula edodes) }\end{array}$ & $\begin{array}{l}\text { Immunomodulatory and pulmonary } \\
\text { cytoprotective effects. }\end{array}$ & [14] \\
\hline 8. & $\begin{array}{l}\beta \text {-glucans (from mushrooms as Lentinula edodes } \\
\text { and Pleurotus ostreatus) }\end{array}$ & Immunomodulating effects. & [170] \\
\hline 9. & $\begin{array}{c}\beta \text {-glucan } \\
\text { (from white button mushroom } \\
\text { Agaricus bisporus) }\end{array}$ & $\begin{array}{l}\text { Interrupts AR (androgen receptor)-mediated } \\
\text { TMPRSS2 (Transmembrane protease serine 2) } \\
\text { expression that is involved in viral entry, through its } \\
\text { AR antagonistic activity; } \\
\text { Attenuates serum pro-inflammatory cytokines and } \\
\text { reduces MDSC (myeloid-derived suppressor cells) } \\
\text { counts that are involved in the host response to viral } \\
\text { infection, through its immunoregulatory activity). }\end{array}$ & [175] \\
\hline 10. & $\begin{array}{c}\text { 1,4- } \alpha \text {-glucan } \\
\text { (from Lentinula edodes) }\end{array}$ & $\begin{array}{c}\text { Modulation and activation of } \\
\text { NK-cells, T-cells, and } \gamma \delta-\mathrm{T} \text { (gamma delta T). }\end{array}$ & [186] \\
\hline 11. & $\begin{array}{c}\beta \text {-glucans } \\
\text { (from edible and medicinal mushrooms) }\end{array}$ & $\begin{array}{l}\text { Support the immune system before, during, and } \\
\text { after COVID-19. }\end{array}$ & [187] \\
\hline 12. & Aminated $\beta$-glucan $(A \beta G)$ & $\begin{array}{l}\text { Potential vaccine adjuvant, immunopotentiator for } \\
\text { simulation of antigen-presenting cells for } \\
\text { T cells' activation. }\end{array}$ & [188-190] \\
\hline 13. & $\begin{array}{c}\beta \text {-glucan } \\
\text { (from yeast, Saccharomysces cerevisiae) }\end{array}$ & $\begin{array}{c}\text { Decreasing platelet activation by increasing } \\
\text { TGF- } \beta 1 \text { production. } \\
\text { Decreasing the concentration of pro-inflammatory } \\
\text { cytokines IL-6, which indirectly activates platelets and } \\
\text { thrombin production. } \\
\text { Prevention of thrombosis during the course } \\
\text { of COVID-19. }\end{array}$ & {$[169,177,191]$} \\
\hline
\end{tabular}


The promising results of studies on mushroom $\beta$-glucan from Agaricus bisporus and Lentinula edodes $[14,175]$ allow us to assume a beneficial effect of these compounds in the prevention, course, and counteracting complications of COVID-19 in the era of the pandemic caused by SARS-CoV-2. Still, there are only a few studies on the promising function of mushroom $\beta$-glucans in the context of COVID-19; such research needs to be continued due to the easy availability and significant amounts of beta-glucans in mushrooms [35], as well as the safety and ease of administration without significant side effects, even in the case of insufficient purification $[14,186,187]$. The advantage of mushroom glucans is that they can be administered orally and have an extremely high safety profile [172].

\subsubsection{Mushroom Beta-Glucans as Prebiotics and Microbiota Modulators}

Mushrooms owe their prebiotic properties to polysaccharides, which are not digested in the intestine. They create excellent conditions for the growth and activity of beneficial bacteria of the digestive tract of the genera Bifidobacterium and Lactobacillus. These polysaccharides include $\beta$-glucans, chitin, hemicelluloses, mannans, and xylans [192]. For example, $\beta$-glucan pullulan has proven prebiotic properties. This polysaccharide administered to the test subjects induced the development of the beneficial bacterial microflora Bifidobacterium [193].

Beta-glucans are resistant to human digestive enzymes and pass through the digestive tract into the intestines, retaining their original structure. Therefore, most mushrooms abundant with beta-glucans can be considered potential sources of prebiotics. Evidence for the prebiotic properties of mushroom polysaccharides is provided in the study by Synytsya et al. [21], who observed that extracts of cultivated mushrooms from Pleurotus genus intensively stimulated the growth of probiotic flora. In their latest in vitro study, Mitsou et al. [194] found that mushrooms rich in $\beta$-glucans may exert beneficial effects in gut microbiota and are crucial in the production of short chain fatty acids (SCFAs). Other authors emphasize that yeast glucans and mushroom glucan polymer complexes are able to stimulate the growth and development of Lactobacillus acidophilus and Bifidobacterium bifidum [195-197]. In their study, Mitsou et al. [194] found that all tested fungi had a positive effect on increased propionate and butyrate production. This indicates the potential of edible mushrooms rich in $\beta$-glucans as prebiotics. In addition, fungi from the genera Pleurotus and Cyclocybe presented beneficial effects on microbiota composition through the growth of Bifidobacterium spp. and populations of Faecalibacterium prausnitzii [194]. Furthermore, the available scientific evidence has shown that non-starch polysaccharides (NSPs) from various products such as oat bran, mushroom, seaweed, pectin, etc. exhibit a protective action in the treatment and prevention of inflammatory bowel disease (IBD) [198]. A decreased Bifidobacerium/Faecalibacterium (B/F) ratio is associated with obesity and type 2 diabetes [199]. Edible mushrooms can increase this ratio and maintain the microbial balance in the gut altered by a high-fat diet. Extracts of Ganoderma lucidum and Antrodia cinnamomea, polysaccharides from Sarcodon aspratus, have been shown to increase the B/F ratio in mice fed a high-fat diet [200-202].

Beta-glucans derived from fungi, due to their diversity of structures and physicochemical properties, can contribute to the growth of specific groups of bacteria that are important for human health. Unlike beta-glucans from other sources, both soluble and insoluble mushroom-derived beta-glucans support the growth of probiotic bacteria that are beneficial to consumer health [203,204].

\section{Conclusions}

$\beta$-glucans are natural molecules that have great therapeutic potential due to their immunomodulatory, antineoplastic, anti-inflammatory, antioxidant, anti-allergic, antibacterial, antifungal, and antiviral properties. Recent reports have indicated great potential for the use of beta-glucans from fungi in the prevention and treatment of COVID-19.

Beta-glucan molecules are characterized by a large diversity not only due to the source of origin (cereals, mushrooms, yeast), but also within a single species of fungus or 
fruiting body. Their properties can also be modified by different extraction and purification conditions. Therefore, it is very important to develop a standardized method for extraction and purification of beta-glucans and evaluation of their structure (number and length of branching and presence of amino acids, proteins, or other substituents), in order to accurately assess their mechanisms of action and potential therapeutic properties.

Previous studies indicated the potential of $\beta$-glucans in the prevention, treatment, and complications of COVID-19 [14,169,170,179-192]. Immunomodulatory, antioxidant, neuroprotective, and antithrombotic activities are of particular interest here. There are still few studies on the use of $\beta$-glucans from edible mushrooms for COVID-19 [14,175]. Edible macrofungi appear to be an excellent source of $\beta$-glucans for clinical applications, due in part to the lack of toxicological risk from fungal toxins. Because of this, edible mushrooms can be used to produce both highly purified $\beta$-glucan preparations as well as less purified cocktails. However, careful studies are needed to determine the desired formulation, to determine dosages, and to determine the feasibility of their use at different stages of COVID-19 disease.

Such data are essential to adequately support the immune system and counter COVID19 complications while not harming it. The growing interest in the role of $\beta$-glucans in the prevention and treatment of COVID-19 may translate favorably into the development of an effective formulation for the prevention and treatment of other viruses that humanity will face in the future. Therefore, further studies on fungal $\beta$-glucans in terms of efficient extraction, purification, their activity, and mechanisms of action are needed for their most appropriate application.

Author Contributions: Conceptualization, I.M.-C. and A.M.W.; investigation, I.M.-C.; writingoriginal draft preparation, I.M.-C.; writing—review and editing, I.M.-C., A.M.W. and K.K.; visualization, I.M.-C.; supervision, A.M.W. All authors have read and agreed to the published version of the manuscript.

Funding: This research received no external funding.

Institutional Review Board Statement: Not applicable.

Informed Consent Statement: Not applicable.

Data Availability Statement: Not applicable.

Acknowledgments: The authors would like to thank their colleagues from the Department of Food Biotechnology for their support during the writing — review and editing.

Conflicts of Interest: The authors declare no conflict of interest.

\section{References}

1. Peintner, U.; Pöder, R. Ethnomycological remarks on the Iceman's fungi. In The Iceman and His Natural Environment; Bortenschlager, S., Oeggl, K., Eds.; Springer: Vienna, Austria, 2000; Volume 4, Chapter 12; pp. 143-150.

2. González, A.; Nobre, C.; Simões, L.S.; Cruz, M.; Loredo, A.; Rodríguez-Jasso, R.M.; Contreras, J.; Texeira, J.; Belmares, R. Evaluation of functional and nutritional potential of a protein concentrate from Pleurotus ostreatus mushroom. Food Chem. 2021, 346, 128884. [CrossRef]

3. Witkowska, A.M.; Zujko, M.E.; Mirończuk-Chodakowska, I. Comparative study of wild edible mushrooms as sources of antioxidants. Int. J. Med. Mushroom 2011, 13, 335-341. [CrossRef]

4. Tran, H.B.; Yamamoto, A.; Matsumoto, S.; Ito, H.; Igami, K.; Miyazaki, T.; Kondo, R.; Shimizu, K. Hypotensive effects and angiotensin-converting enzyme inhibitory peptides of reishi (Ganoderma lingzhi) auto-digested extract. Molecules 2014, 19, 13473-13485. [CrossRef] [PubMed]

5. Zhang, C.; Li, J.; Wang, J.; Song, X.; Zhang, J.; Wu, S.; Hu, C.; Gong, Z.; Jia, L. Antihyperlipidaemic and hepatoprotective activities of acidic and enzymatic hydrolysis exopolysaccharides from Pleurotus eryngii SI-04. BMC Complement. Altern. Med. 2017, 17, 403. [CrossRef] [PubMed]

6. Liu, Y.; Wang, C.; Li, J.; Mei, Y.; Liang, Y. Hypoglycemic and Hypolipidemic Effects of Phellinus Linteus Mycelial Extract from Solid-State Culture in A Rat Model of Type 2 Diabetes. Nutrients 2019, 11, 296. [CrossRef] [PubMed]

7. Kuo, H.C.; Liu, Y.W.; Lum, C.C.; Hsu, K.D.; Lin, S.P.; Hsieh, C.W.; Lin, H.W.; Lu, T.Y.; Cheng, K.C. Ganoderma formosanum exopolysaccharides inhibit tumor growth via immunomodulation. Int. J. Mol. Sci. 2021, 22, 11251. [CrossRef] 
8. Ahmad, M.F.; Ahmad, F.A.; Khan, M.I.; Alsayegh, A.A.; Wahab, S.; Alam, M.I.; Ahmed, F. Ganoderma lucidum: A potential source to surmount viral infections through $\beta$-glucans immunomodulatory and triterpenoids antiviral properties. Int. J. Biol. Macromol. 2021, 187, 769-779. [CrossRef]

9. Moorlag, S.J.C.F.M.; Khan, N.; Novakovic, B.; Kaufmann, E.; Jansen, T.; van Crevel, R.; Divangahi, M.; Netea, M.G. $\beta$-Glucan Induces Protective Trained Immunity against Mycobacterium tuberculosis Infection: A Key Role for IL-1. Cell Rep. 2020, 31,107634 [CrossRef]

10. Afiukwa, C.A.; Ugwu, O.P.C.; Okoli, S.O.; Idenyi, J.N.; Ossai, E.C. Contents of some vitamins in five edible mushroom verities consumed in Abakaliki Metropolis, Nigeria. Res. J. Pharm. Biol. Chem. Sci. 2013, 4, 805-812.

11. Dubost, N.J.; Ou, B.; Beeleman, R.B. Quantification of polyphenols and ergothioneine in cultivated mushrooms and correlation to total antioxidant capacity. Food Chem. 2007, 105, 727-735. [CrossRef]

12. Zięba, P.; Sękara, A.; Bernaś, E.; Krakowska, A.; Sułkowska-Ziaja, K.; Kunicki, E.; Suchanek, M.; Muszyńska, B. Supplementation with magnesium salts-a strategy to increase nutraceutical value of Pleurotus djamor fruiting bodies. Molecules 2021, $26,3273$. [CrossRef] [PubMed]

13. Cerletti, C.; Esposito, S.; Iacoviello, L. Edible mushrooms and beta-glucans: Impact on human health. Nutrients 2021, 13, 2195. [CrossRef]

14. Murphy, E.J.; Masterson, C.; Rezoagli, E.; O’Toole, D.; Major, I.; Stack, G.D.; Lynch, M.; Laffey, J.G.; Rowan, N.J. $\beta$-Glucan extracts from the same edible shiitake mushroom Lentinus edodes produce differential. In-Vitro immunomodulatory and pulmonary cytoprotective effects- Implications for coronavirus disease (COVID-19) immunotherapies. Sci. Total Environ. 2020, 732, 139330. [CrossRef] [PubMed]

15. Singdevsachan, S.K.; Mishra, P.A.J.; Baliyarsingh, B.; Tayung, K.; Thatoi, H. Mushroom polysaccharides as potential prebiotics with their antitumor and immunomodulating properties: A review. Bioact. Carbohydr. Diet. Fibre 2016, 7, 1-14. [CrossRef]

16. He, X.; Wang, X.; Fang, J.; Chang, Y.; Ning, N.; Guo, H.; Huang, L.; Huang, X.; Zhao, Z. Structures, biological activities, and industrial applications of the polysaccharides from Hericium erinaceus (Lion's Mane) mushroom: A review. Int. J. Biol. Macromol. 2017, 97, 228-237. [CrossRef]

17. Ruthes, A.C.; Smiderle, F.R.; Iacomini, M. Mushrooms heteropolysaccharides. A review on their sources, structure and biological effects. Carbohydr. Polym. 2016, 136, 358-375. [CrossRef] [PubMed]

18. Nitschke, J.; Modick, H.; Busch, E.; von Rekowski, R.W.; Altenbach, H.J.; Mölleken, H. A new colorimetric method to quantify $\beta-1,3-1,6$-glucans in comparison with total $\beta$-1,3-glucans in edible mushrooms. Food Chem. 2011, 127, 791-796. [CrossRef]

19. Ruthes, A.C.; Smiderle, F.R.; Iacomini, M. D-Glucans from edible mushrooms: A review on the extraction, purification and chemical characterization approaches. Carbohydr. Polym. 2015, 117, 753-761. [CrossRef] [PubMed]

20. Xiao, Z.; Zhou, W.; Zhang, Y. Fungal polysaccharides. Adv. Pharmacol. 2020, 87, 277-299. [CrossRef]

21. Synytsya, A.; Míčková, K.; Synytsya, A.; Jablonský, I.; Spěváček, J.; Erban, V.; Kováǎíková, E.; Čopíková, J. Glucans from fruit bodies of cultivated mushrooms Pleurotus ostreatus and Pleurotus eryngii: Structure and potential prebiotics activity. Carbohydr. Polym. 2009, 76, 548-556. [CrossRef]

22. Synytsya, A.; Novak, M. Structural analysis of glucans. Ann. Transl. Med. 2014, 2, 17. [CrossRef]

23. Sheng, K.; Wang, C.; Chen, B.; Kang, M.; Wang, M.; Liu, K.; Wang, M. Recent advances in polysaccharides from Lentinus edodes (Berk.): Isolation, structures and bioactivities. Food Chem. 2021, 358, 129883. [CrossRef] [PubMed]

24. Chakraborty, N.; Banerjee, A.; Sarkar, A.; Ghosh, S.; Acharya, K. Mushroom Polysaccharides: A Potent Immune-Modulator. Biointerface Res. Appl. Chem. 2021, 11, 8915-8930. [CrossRef]

25. Kaur, R.; Sharma, M.; Ji, D.; Xu, M.; Agyei, D. Structural Features, Modification, and Functionalities of Beta-Glucan. Fibers 2020, 8, 1. [CrossRef]

26. Villares, A.; Mateo-Vivaracho, L.; Guillamon, E. Structural features and healthy properties of polysaccharides occurring in mushrooms. Agriculture 2012, 2, 452-471. [CrossRef]

27. Chen, S.; Sathuvan, M.; Zhang, X.; Zhang, W.; Tang, S.; Liu, Y.; Cheong, K.L. Characterization of polysaccharides from different species of brown seaweed using saccharide mapping and chromatographic analysis. BMC Chem. 2021, 15, 1. [CrossRef] [PubMed]

28. Zhang, H.; Xiong, Y.; Bakry, A.M.; Xiong, S.; Yin, T.; Zhang, B.; Huang, J.; Liu, Z.; Huang, Q. Effect of yeast $\beta$-glucan on gel properties, spatial structure and sensory characteristics of silver carp surimi. Food Hydrocol. 2019, 88, 256-264. [CrossRef]

29. Meng, Y.; Lyu, F.; Xu, X. Zhang, L. Recent advances in chain conformation and bioactivities of triple-helix polysaccharides. Biomacromolecules 2020, 21, 1653-1677. [CrossRef]

30. Wang, Q.; Ellis, P.R. Oat $\beta$-glucan: Physico-chemical characteristics in relation to its blood-glucose and cholesterol-lowering properties. Br. J. Nutr. 2014, 112, S4-S13. [CrossRef] [PubMed]

31. Henrion, M.; Francey, C.; Lê, K.A.; Lamothe, L. Cereal B-Glucans: The Impact of Processing and How It Affects Physiological Responses. Nutrients 2019, 11, 1729. [CrossRef]

32. Mathews, R.; Kamil, A.; Chu, Y. Global review of heart health claims for oat beta-glucan products. Nutrition 2021, 78, 78-97. [CrossRef] [PubMed]

33. Boutros, J.A.; Magee, A.S.; Cox, D. Comparison of structural differences between yeast $\beta$-glucan sourced from different strains of saccharomyces cerevisiae and processed using proprietary manufacturing processes. Food Chem. 2022, 367, 130708. [CrossRef] [PubMed] 
34. Du, B.; Meenu, M.; Liu, H.; Xu, B.A. Concise Review on the Molecular Structure and Function Relationship of $\beta$-Glucan. Int. J. Mol. Sci. 2019, 20, 4032. [CrossRef]

35. Mirończuk-Chodakowska, I.; Witkowska, A.M. Evaluation of Polish wild Mushrooms as Beta-Glucan Sources. Int. J. Environ. Res. Public. Health 2020, 17, 7299. [CrossRef]

36. Lee, Y.T.; Kim, Y.S. Water-solubility of $\beta$-glucans in various edible mushrooms-research note. J. Food Sci. Nutr. 2005, 10, $294-297$. [CrossRef]

37. Ina, K.; Kataoka, T.; Ando, T. The use of lentinan for treating gastric cancer. Anticancer Agents Med. Chem. 2013, 13, 681-688. [CrossRef]

38. Cognigni, V.; Ranallo, N.; Tronconi, F.; Morgese, F.; Berardi, R. Potential benefit of $\beta$-glucans as adjuvant therapy in immunooncology: A review. Explor. Target. Antitumor Ther. 2021, 2, 122-138. [CrossRef]

39. Benson, K.F.; Stamets, P.; Davis, R.; Nally, R.; Taylor, A.; Slater, S.; Jensen, G.S. The mycelium of the Trametes versicolor (Turkey tail) mushroom and its fermented substrate each show potent and complementary immune activating properties in vitro. BMC Complement. Altern. Med. 2019, 19, 342. [CrossRef]

40. Maehara, Y.; Tsujitani, S.; Saeki, H.; Oki, E.; Yoshinaga, K.; Emi, Y.; Morita, M.; Kohnoe, S.; Kakeji, Y.; Yano, T.; et al. Biological mechanism and clinical effect of protein-bound polysaccharide K (KRESTIN $\left.{ }^{\circledR}\right)$ : Review of development and future perspectives. Surg. Today 2012, 42, 8-28. [CrossRef] [PubMed]

41. Grzybek, J.; Zgórniak-Nowosielska, I.; Kohlmünzer, S. Antitumor and Cytotoxic Activity of Tylopilan, a Fungal Polysaccharide from Tylopilus felleus Fruit Bodies. Planta Med. 1990, 56, 670-671. [CrossRef]

42. Zhang, Y.; Li, S.; Wang, X.; Zhang, L.; Cheung, P.C.K. Advances in lentinan: Isolation, structure, chain conformation and bioactivities. Food Hydrocol. 2011, 25, 196-206. [CrossRef]

43. Karácsonyi, Š.; Kuniak, L'. Polysaccharides of Pleurotus ostreatus: Isolation and structure of pleuran, an alkali-insoluble $\beta$-d-glucan. Carbohydr. Polym. 1994, 24, 107-111. [CrossRef]

44. Zhang, Y.; Kong, H.; Fang, Y.; Nishinari, K.; Phillips, G.O. Schizophyllan: A review on its structure, properties, bioactivities and recent developments. Bioact. Carbohydr. Diet. Fibre 2013, 1, 53-71. [CrossRef]

45. Masuda, Y.; Murata, Y.; Hayashi, M.; Nanba, H. Inhibitory effect of MD-Fraction on tumor metastasis: Involvement of NK cell activation and suppression of intercellular adhesion molecule (ICAM)-1 expression in lung vascular endothelial cells. Biol. Pharm. Bull. 2008, 31, 1104-1108. [CrossRef] [PubMed]

46. Wu, J.Y.; Siu, K.C.; Geng, P. Bioactive Ingredients and Medicinal Values of Grifola frondosa (Maitake). Foods 2021, 10, 95. [CrossRef]

47. Coviello, T.; Palleschi, A.; Grassi, M.; Matricardi, P.; Bocchinfuso, G.; Alhaique, F. Scleroglucan: A Versatile Polysaccharide for Modified Drug Delivery. Molecules 2005, 10, 6-33. [CrossRef]

48. Chihara, G.; Hamuro, J.; Maeda, Y.; Arai, Y.; Fukuoka, F. Fractionation and purification of the polysaccharides with marked antitumor activity, especially lentinan, from Lentinus edodes (Berk.) Sing. (an edible mushroom). Cancer Res. 1970, 30, $2776-2781$.

49. Giavasis, I. Bioactive fungal polysaccharides as potential functional ingredients in food and nutraceuticals. Curr. Opin. Biotechnol. 2014, 26, 162-173. [CrossRef]

50. Wu, X.; Zheng, Z.; Guo, T.; Wang, K.; Zhang, Y. Molecular dynamics simulation of lentinan and its interaction with the innate receptor dectin-1. Int. J. Biol. Macromol. 2021, 171, 527-538. [CrossRef]

51. Wang, K.P.; Zhang, Q.L.; Liu, Y.; Wang, J.; Cheng, Y.; Zhang, Y. Structure and inducing tumor cell apoptosis activity of polysaccharides isolated from Lentinus edodes. J. Agric. Food Chem. 2013, 61, 9849-9858. [CrossRef]

52. Zhang, Y.; Liu, Y.; Zhou, Y.; Zheng, Z.; Tang, W.; Song, M.; Wang, J.; Wang, K. Lentinan inhibited colon cancer growth by inducing endoplasmic reticulum stress-mediated autophagic cell death and apoptosis. Carbohydr. Polym. 2021, 267, 118154. [CrossRef]

53. Zi, Y.; Jiang, B.; He, C.; Liu, L. Lentinan inhibits oxidative stress and inflammatory cytokine production induced by benzo(a)pyrene in human keratinocytes. J. Cosmet. Dermatol. 2020, 19, 502-507. [CrossRef]

54. Morales, D.; Rutckeviski, R.; Villalva, M.; Abreu, H.; Soler-Rivas, C.; Santoyo, S.; Iacomini, M.; Smiderle, F.R. Isolation and comparison of $\alpha$ - and $\beta$-D-glucans from shiitake mushrooms (Lentinula edodes) with different biological activities. Carbohydr. Polym. 2020, 229, 115521. [CrossRef] [PubMed]

55. Pan, W.; Jiang, P.; Zhao, J.; Shi, H.; Zhang, P.; Yang, X.; Biazik, J.; Hu, M.; Hua, H.; Ge, X.; et al. $\beta$-Glucan from Lentinula edodes prevents cognitive impairments in high-fat diet-induced obese mice: Involvement of colon-brain axis. J. Transl. Med. 2021, 19, 54. [CrossRef] [PubMed]

56. Kikumoto, S.; Miyajima, T.; Yoshizumi, S.; Fujimoto, S.; Kimura, K. Polysaccharide produced by Schizophyllum commune. 1. Formation and some properties of an extracellular polysaccharide. J. Agric. Chem. Soc. Jpn. 1970, 44, 337-342.

57. Sutivisedsak, N.; Leathers, T.D.; Price, N.P.J. Production of schizophyllan from distiller's dried grains with solubles by diverse strains of Schizophyllum commune. Springer Plus 2013, 2, 476. [CrossRef]

58. Chen, Z.; Yin, C.; Fan, X.; Ma, K.; Yao, F.; Zhou, R.; Shi, D.; Cheng, W.; Gao, H. Characterization of physicochemical and biological properties of Schizophyllum commune polysaccharide extracted with different methods. Int. J. Biol. Macromol. 2020, 156, 1425-1434. [CrossRef]

59. Thongsiri, C.; Nagai-Yoshioka, Y.; Yamasaki, R.; Adachi, Y.; Usui, M.; Nakashima, K.; Nishihara, T.; Ariyoshi, W. Schizophyllum commune $\beta$-glucan: Effect on interleukin-10 expression induced by lipopolysaccharide from periodontopathic bacteria. Carbohydr. Polym. 2021, 253, 117285. [CrossRef] [PubMed] 
60. Lemieszek, M.; Rzeski, W. Anticancer properties of polysaccharides isolated from fungi of the Basidiomycetes class. Contemp. Oncol. 2012, 16, 285-289. [CrossRef] [PubMed]

61. Khan, A.A.; Gani, A.; Khanday, F.A.; Masoodi, F.A. Biological and pharmaceutical activities of mushroom $\beta$-glucan discussed as a potential functional food ingredient. Bioact. Carbohydr. Diet. Fibre 2018, 16, 1-13. [CrossRef]

62. Yamashita, K.; Ougolkov, A.V.; Nakazato, H.; Ito, K.; Ohashi, Y.; Kitakata, H.; Yasumoto, K.; Omote, K.; Mai, M.; Takahashi, Y.; et al. Adjuvant immunochemotherapy with protein-bound polysaccharide $\mathrm{K}$ for colon cancer in relation to oncogenic beta-catenin activation. Dis. Colon. Rectum. 2007, 50, 1169-1181. [CrossRef]

63. Chang, Y.; Zhang, M.; Jiang, Y.; Liu, Y.; Luo, H.; Hao, C.; Zeng, P.; Zhang, L. Preclinical and clinical studies of Coriolus versicolor polysaccharopeptide as an immunotherapeutic in China. Discov. Med. 2017, 23, 207-219.

64. Masuda, Y.; Inoue, H.; Ohta, H.; Miyake, A.; Konishi, M.; Nanba, H. Oral administration of soluble $\beta$-glucans extracted from Grifola frondosa induces systemic antitumor immune response and decreases immunosuppression in tumor-bearing mice. Int. J. Cancer 2013, 133, 108-119. [CrossRef]

65. Mao, G.H.; Ren, Y.; Feng, W.W.; Li, Q.; Wu, H.Y.; Jin, D.; Zhao, T.; Xu, C.Q.; Yang, L.Q.; Wu, X.Y. Antitumor and immunomodulatory activity of a water-soluble polysaccharide from Grifola frondosa. Carbohydr. Polym. 2015, 134, 406-412. [CrossRef]

66. Chen, Y.H.; Lee, C.H.; Hsu, T.H.; Lo, H.C. Submerged-Culture Mycelia and Broth of the Maitake Medicinal Mushroom Grifola frondosa (Higher Basidiomycetes) Alleviate Type 2 Diabetes-Induced Alterations in Immunocytic Function. Int. J. Med. Mushrooms 2015, 17, 541-556. [CrossRef]

67. Seo, Y.R.; Patel, D.K.; Shin, W.C.; Sim, W.S.; Lee, O.H.; Lim, K.T. Structural Elucidation and Immune-Enhancing Effects of Novel Polysaccharide from Grifola frondosa. Biomed. Res. Int. 2019, 2019, 7528609. [CrossRef] [PubMed]

68. Jesenak, M.; Majtan, J.; Rennerova, Z.; Kyselovic, J.; Banovcin, P.; Hrubisko, M. Immunomodulatory effect of pleuran ( $\beta$-glucan from Pleurotus ostreatus) in children with recurrent respiratory tract infections. Int. Immunopharmacol. 2013, 15, 395-399. [CrossRef] [PubMed]

69. Majtan, J. Pleuran ( $\beta$-glucan from Pleurotus ostreatus): An effective nutritional supplement against upper respiratory tract infections? Med. Sport Sci. 2013, 59, 57-61. [CrossRef]

70. Urbancikova, I.; Hudackova, D.; Majtan, J.; Rennerova, Z.; Banovcin, P.; Jesenak, M. Efficacy of Pleuran ( $\beta$-Glucan from Pleurotus ostreatus) in the Management of Herpes Simplex Virus Type 1 Infection. Evid. Based. Complement. Altern. Med. 2020, 2020, 8562309. [CrossRef] [PubMed]

71. Zhang, M.; Cui, S.W.; Cheung, P.C.K.; Wang, Q. Antitumor polysaccharides from mushrooms: A review on their isolation process, structural characteristic and antitumor activity. Trends Food Sci. Technol. 2007, 18, 4-19. [CrossRef]

72. Ping, Z.; Xu, H.; Liu, T.; Huang, J.; Meng, Y.; Xu, X.; Li, W.; Zhang, L. Anti-hepatoma activity of the stiff branched $\beta$-d-glucan and effects of molecular weight. J. Mater. Chem. B 2016, 4, 4565-4573. [CrossRef]

73. Chan, G.C.; Chan, W.K.; Sze, D.M. The effects of beta-glucan on human immune and cancer cells. J. Hematol. Oncol. 2009, 2, 25. [CrossRef] [PubMed]

74. Roupas, P.; Keogh, J.; Noakes, M.; Margetts, C.; Taylor, P. The role of edible mushrooms in health. Evaluation of the evidence. J. Funct. Foods 2012, 4, 687-709. [CrossRef]

75. Gaullier, J.M.; Sleboda, J.; Øfjord, E.S.; Ulvestad, E.; Nurminiemi, M.; Moe, C.; Tor, A.; Gudmundsen, O. Supplementation with a soluble $\beta$-glucan exported from Shiitake medicinal mushroom, Lentinus edodes (Berk.) singer mycelium: A crossover, placebo-controlled study in healthy elderly. Int. J. Med. Mushrooms 2011, 13, 319-326. [CrossRef]

76. Motta, F.; Gershwin, M.E.; Selmi, C. Mushrooms and immunity. J. Autoimmun. 2021, 117, 102576. [CrossRef]

77. Herre, J.; Gordon, S.; Brown, G.D. Dectin-1 and its role in the recognition of $\beta$-glucans by macrophages. Mol. Immunol. 2004, 40, 869-876. [CrossRef] [PubMed]

78. Marakalala, M.J.; Williams, D.L.; Hoving, J.C.; Engstad, R.; Netea, M.G.; Brown, G.D. Dectin-1 plays a redundant role in the immunomodulatory activities of B-glucan-rich ligands in vivo. Microbes Infect. 2013, 15, 511-515. [CrossRef] [PubMed]

79. Vidya, M.K.; Kumar, V.G.; Sejian, V.; Bagath, M.; Krishnan, G.; Bhatta, R. Toll-like receptors: Significance, ligands, signaling pathways, and functions in mammals. Int. Rev. Immunol. 2018, 37, 20-36. [CrossRef]

80. Kawai, T.; Akira, S. Toll-like Receptors and Their Crosstalk with Other Innate Receptors in Infection and Immunity. Immunity 2011, 34, 637-650. [CrossRef] [PubMed]

81. Chen, J.; Seviour, R. Medical importance of fungal $\beta-(1-3),(1-6)$-glucans. Mycol. Res. 2007, 111, 635-652. [CrossRef]

82. Grassin-Delyle, S.; Abrial, C.; Salvator, H.; Brollo, M.; Naline, E.; Devillier, P. The Role of Toll-Like Receptors in the Production of Cytokines by Human Lung Macrophages. J. Innate Immun. 2020, 12, 63-73. [CrossRef]

83. Lukácsi, S.; Nagy-Baló, Z.; Erdei, A.; Sándor, N.; Bajtay, Z. The role of CR3 (CD11b/CD18) and CR4 (CD11c/CD18) in complementmediated phagocytosis and podosome formation by human phagocytes. Immunol. Lett. 2017, 189, 64-72. [CrossRef] [PubMed]

84. Kim, H.S.; Hong, J.T.; Kim, Y.; Han, S.B. Stimulatory Effect of $\beta$-glucans on immune cells. Immune Netw. 2011, 11, 191-195. [CrossRef]

85. Vetvicka, V.; Thornton, B.P.; Wieman, T.J.; Ross, G.D. Targeting of natural killer cells to mammary carcinoma via naturally occurring tumor cell-bound iC3b and beta-glucan-primed CR3 (CD11b/CD18). J. Immunol. 1997, 159, 599-605. [PubMed]

86. Zani, I.A.; Stephen, S.L.; Mughal, N.A.; Russell, D.; Homer-Vanniasinkam, S.; Wheatcroft, S.B.; Ponnambalam, S. Scavenger Receptor Structure and Function in Health and Disease. Cells 2015, 4, 178-201. [CrossRef] 
87. Rice, P.J.; Kelley, J.L.; Kogan, G.; Ensley, H.E.; Kalbfleisch, J.H.; Browder, I.W.; Williams, D.L. Human monocytes scavenger receptors are pattern recognition receptors for (1-3)- $\beta$-D-glucans. J. Leukoc. Biol. 2002, 72, 140-146. [PubMed]

88. Batbayar, S.; Lee, D.H.; Kim, H.W. Immunomodulation of fungal $\beta$-glucan in host defense signaling by dectin-1. Biomol. Ther. 2012, 20, 433-445. [CrossRef]

89. Chatterjee, S.; Balram, A.; Li, W. Convergence: Lactosylceramide-Centric Signaling Pathways Induce Inflammation, Oxidative Stress, and Other Phenotypic Outcomes. Int. J. Mol. Sci. 2021, 22, 1816. [CrossRef]

90. Nguyen, G.T.; Green, E.R.; Mecsas, J. Neutrophils to the ROScue: Mechanisms of NADPH Oxidase Activation and Bacterial Resistance. Front. Cell Infect. Microbiol. 2017, 7, 373. [CrossRef]

91. Wu, Y.L.; Han, F.; Luan, S.S.; Ai, R.; Zhang, P.; Li, H.; Chen, L.X. Triterpenoids from Ganoderma lucidum and Their Potential Anti-inflammatory Effects. J. Agric. Food Chem. 2019, 67, 5147-5158. [CrossRef]

92. Schwartzand, B.; Hadar, Y. Possible mechanisms of action of mushroom-derived glucans on inflammatory bowel disease and associated cancer. Ann. Transl. Med. 2014, 2, 19. [CrossRef]

93. Bergendiova, K.; Tibenska, E.; Majtan, J. Pleuran ( $\beta$-glucan from Pleurotus ostreatus) supplementation, cellular immune response and respiratory tract infections in athletes. Eur. J. Appl. Physiol. 2011, 111, 2033-2040. [CrossRef]

94. Mizuno, M.; Minato, K.; Kawakami, S.; Tatsuoka, S.; Denpo, Y.; Tsuchida, H. Contents of anti-tumor polysaccharides in certain mushrooms and their immunomodulating activities. Food Sci. Technol. Res. 2001, 7, 31-34. [CrossRef]

95. Pires, A.R.A.; Ruthes, A.C.; Cadena, S.M.S.C.; Acco, A.; Gorin, P.A.J.; Iacomini, M. Cytotoxic effect of Agaricus bisporus and Lactarius rufus $\beta$-D-glucans on HepG2 cells. Int. J. Biol. Macromol. 2013, 58, 95-103. [CrossRef]

96. Mizuno, T. The Extraction and Development of Antitumor-Active Polysaccharides from Medicinal Mushrooms in Japan (Review). Int. J. Med. Mushrooms 1999, 1, 9-29. [CrossRef]

97. Higashi, D.; Seki, K.; Ishibashi, Y.; Egawa, Y.; Koga, M.; Sasaki, T.; Hirano, K.; Mikami, K.; Futami, K.; Maekawa, T.; et al. The effect of lentinan combination therapy for unresectable advanced gastric cancer. Anticancer Res. 2012, 32, $2365-2368$.

98. Sasaki, S.; Izumi, H.; Morimoto, Y.; Sakurai, K.; Mochizuki, S. Induction of potent cell growth inhibition by schizophyllan/K-ras antisense complex in combination with gemcitabine. Bioorg. Med. Chem. 2020, 28, 115668. [CrossRef]

99. Yamasaki, A.; Onishi, H.; Imaizumi, A.; Kawamoto, M.; Fujimura, A.; Oyama, Y.; Katano, M. Protein-bound Polysaccharide-K Inhibits Hedgehog Signaling Through Down-regulation of MAML3 and RBPJ Transcription Under Hypoxia, Suppressing the Malignant Phenotype in Pancreatic Cancer. Anticancer Res. 2016, 36, 3945-3952.

100. Cheung, N.K.; Modak, S.; Vickers, A.; Knuckles, B. Orally administered beta-glucans enhance anti-tumor effects of monoclonal antibodies. Cancer Immunol. Immunother. 2002, 51, 557-564. [CrossRef]

101. Chen, J.; Zhang, X.D.; Jiang, Z. The application of fungal $\beta$-glucans for the treatment of colon cancer. Anticancer Agents Med. Chem. 2013, 13, 725-730. [CrossRef]

102. Lavi, I.; Nimri, L.; Levinson, D.; Peri, I.; Hadar, Y.; Schwartz, B. Glucans from the edible mushroom Pleurotus pulmonarius inhibit colitis-associated colon carcinogenesis in mice. J. Gastroenterol. 2012, 47, 504-518. [CrossRef] [PubMed]

103. Turunen, K.T.; Pletsa, V.; Georgiadis, P.; Triantafillidis, J.K.; Karamanolis, D.; Kyriacou, A. Impact of $\beta$-glucan on the Fecal Water Genotoxicity of Polypectomized Patients. Nutr. Cancer 2016, 68, 560-567. [CrossRef] [PubMed]

104. Vetvicka, V.; Vetvickova, J. Combination of glucan, resveratrol and vitamin C demonstrates strong anti-tumor potential. Anticancer Res. 2012, 32, 81-87.

105. Fujimoto, S.; Furue, H.; Kimura, T.; Kondo, T.; Orita, K.; Taguchi, T.; Yoshida, K.; Ogawa, N. Clinical outcome of postoperative adjuvant immunochemotherapy with sizofiran for patients with resectable gastric cancer: A randomised controlled study. Eur. J. Cancer 1991, 27, 1114-1118. [CrossRef]

106. Chaichian, S.; Moazzami, B.; Sadoughi, F.; Kashani, H.H.; Zaroudi, M.; Asemi, Z. Functional activities of beta-glucans in the prevention or treatment of cervical cancer. J. Ovarian Res. 2020, 13, 24. [CrossRef] [PubMed]

107. Roopngam, P.E. Increased Response of Human T-Lymphocytes by Dendritic Cells Pulsed with HPV16E7 and Pleurotus sajor-caju$\beta$-glucan (PBG). Iran. J. Immunol. 2018, 15, 246-255. [CrossRef]

108. Steimbach, L.; Borgmann, A.V.; Gomar, G.G.; Hoffmann, L.V.; Rutckeviski, R.; de Andrade, D.P.; Smiderle, F.R. Fungal betaglucans as adjuvants for treating cancer patients-A systematic review of clinical trials. Clin. Nutr. 2021, 40, 3104-3113. [CrossRef] [PubMed]

109. Li, X.; Ma, L.; Zhang, L. Molecular basis for Poria cocos mushroom polysaccharide used as an antitumor drug in China. Prog. Mol. Biol. Transl. Sci. 2019, 163, 263-296. [CrossRef]

110. Vetvicka, V.; Teplyakova, T.V.; Shintyapina, A.B.; Korolenko, T.A. Effects of medicinal fungi-derived $\beta$-glucan on tumor progression. J. Fungi 2021, 7, 250. [CrossRef]

111. Carbonero, E.R.; Gracher, A.H.P.; Komura, D.L.; Marcon, R.; Freitas, C.S.; Baggio, C.H.; Santos, A.R.S.; Torri, G.; Gorin, P.A.J.; Iacomini, M. Lentinus edodes heteroglucan: Antinociceptive and anti-inflamatory effects. Food Chem. 2008, 111, 531-537. [CrossRef]

112. Komura, D.L.; Carbonero, E.R.; Gracher, A.H.P.; Baggio, C.H.; Freitas, C.S.; Marcon, R.; Santos, A.R.S.; Gorin, P.A.J.; Iacomini, M. Structure of Agaricus spp. fucogalactans and their anti-inflamatory and aninociceptive properties. Bioresour. Technol. 2010, 101, 6192-6199. [CrossRef] [PubMed]

113. Ruthes, A.C.; Carbonero, E.R.; Córodva, M.M.; Baggio, C.H.; Santos, A.R.S.; Sassaki, G.L.; Cipriani, T.R.; Gorin, P.A.J.; Iacomini, M. Lactarius rufus (1-3),(1-6)- $\beta$-D-glucans: Structure, antinociceptive and anti-inflammatory effects. Carbohydr. Polym. 2013, 94, 129-136. [CrossRef] [PubMed] 
114. Smiderle, F.R.; Olsen, L.M.; Carbonero, E.R.; Beggio, C.H.; Freitas, C.S.; Marcon, R.; Santos, A.R.S.; Gorin, P.A.J.; Iacomini, M. Anti-inflammatory and analgesic properties in a rodent model of a (1-3),(1-6)-linked beta-glucan isolated from Pleurotus pulmonarius. Eur. J. Pharmacol. 2008, 597, 86-91. [CrossRef] [PubMed]

115. Du, B.; Lin, C.; Bian, Z.; Xu, B. An insight into anti-inflammatory effects of fungal beta-glucans. Trends Food Sci. Technol. 2015, 41, 49-59. [CrossRef]

116. Liu, D.Z.; Liang, H.J.; Chen, C.H.; Su, C.H.; Lee, T.H.; Huang, C.T.; Hou, W.C.; Lin, S.Y.; Zhong, W.B.; Lin, P.J.; et al. Comparative anti-infalmmatory characterization of wild fruiting body, liquid-state fermentation, and solid-state culture of Taiwanofungus camhoratus in microglia and the mechanism of its action. J. Ethnopharmacol. 2007, 113, 45-53. [CrossRef] [PubMed]

117. Padilha, M.M.; Avila, A.A.L.; Sousa, P.J.C.; Cardoso, L.G.V.; Perazzo, F.F.; Carvalho, J.C.T. Anti-inflammatory activity of aqueous and alkaline extracts from mushrooms (Agaricus blazei Murill). J. Med. Food. 2009, 12, 359-364. [CrossRef]

118. Piskov, S.; Timchenko, L.; Grimm, W.D.; Rzhepakovsky, I.; Avanesyan, S.; Sizonenko, M.; Kurchenko, V. Effects of Various Drying Methods on Some Physico-Chemical Properties and the Antioxidant Profile and ACE Inhibition Activity of Oyster Mushrooms (Pleurotus ostreatus). Foods 2020, 9, 160. [CrossRef]

119. Zhang, Y.; Dai, L.; Kong, X.; Chen, L. Characterization and in vitro antioxidant activities of polysaccharides from Pleurotus ostreatus. Int. J. Biol. Macromol. 2012, 51, 259-265. [CrossRef]

120. Telles, C.B.S.; Sabry, D.A.; Alimeda-Lima, J.; Costa, M.S.S.P.; Melo-Silveira, R.F.; Trindade, E.S.; Sassaki, G.L.; Wisbeck, E.; Furlan, S.A.; Leite, E.L.; et al. Sulfation of the extracellular polysaccharide produced by the edible mushroom Pleurotus sajor-caju alters its antioxidant, anticoagulant and antiproliferative properties in vitro. Carbohydr. Polym. 2011, 85, 514-521. [CrossRef]

121. Vamanu, E. Antioxidant properties of polysaccharides obtained by batch cultivation of Pleurotus ostreatus mycelium. Nat. Prod. Res. 2013, 27, 1115-1118. [CrossRef]

122. Lai, M.N.; Ng, L.T. Antioxidant and antiedema properties of solid-state cultures honey mushrooms, Armillaria mellea (higher Basidiomycetes), extracts and their polysaccharide and polyphenol contents. Int. J. Med. Mushrooms 2013, 15, 1-8. [CrossRef]

123. Jhan, M.H.; Yeh, C.H.; Tsai, C.C.; Kao, C.T.; Chang, C.K.; Hsieh, C.W. Enhancing the Antioxidant Ability of Trametes versicolor Polysaccharopeptides by an Enzymatic Hydrolysis Process. Molecules 2016, 21, 1215. [CrossRef] [PubMed]

124. Ker, Y.B.; Chen, K.C.; Chyau, C.C.; Chen, C.C.; Guo, J.H.; Hsieh, C.L.; Wang, H.E.; Peng, C.C.; Chang, C.H.; Peng, R.Y. Antioxidant capability of polysaccharides fractionated from submerge-cultured Agaricus blazei mycelia. J. Agric. Food Chem. 2005, 53, 7052-7058. [CrossRef] [PubMed]

125. Diallo, I.; Boudard, F.; Morel, S.; Vitou, M.; Guzman, C.; Saint, N.; Michel, A.; Rapior, S.; Traoré, L.; Poucheret, P.; et al. Antioxidant and Anti-Inflammatory Potential of Shiitake Culinary-Medicinal Mushroom, Lentinus edodes (Agaricomycetes), Sporophores from Various Culture Conditions. Int. J. Med. Mushrooms 2020, 22, 535-546. [CrossRef]

126. Rani, P.; Lal, M.R.; Maheshwari, U.; Krishnan, S. Antioxidant Potential of Lingzhi or Reishi Medicinal Mushroom, Ganoderma lucidum (Higher Basidiomycetes) Cultivated on Artocarpus heterophyllus Sawdust Substrate in India. Int. J. Med. Mushrooms 2015, 17, 1171-1177. [CrossRef] [PubMed]

127. Mau, J.L.; Lin, H.C.; Chen, C.C. Antioxidant properties of several medicinal mushrooms. J Agric. Food Chem. 2002, 50, 6072-6077. [CrossRef] [PubMed]

128. Dore, C.M.; Alves, M.G.; da Santos, M.G.L.; de Souza, L.A.; Baseia, I.G.; Leite, E.L. Antioxidant and anti-inflammatory properties of an extract rich in polysaccharides of the mushroom Polyporus dermoporus. Antioxidants 2014, 3, 730-744. [CrossRef]

129. Fu, L.; Wang, Y.; Yang, Y.; Hao, L. Evaluation of the antioxidant activity of extracellular polysaccharides from Morchella esculenta. Food Funct. 2013, 4, 871-879. [CrossRef]

130. Kogan, G.; Pajtinka, M.; Babincova, M.; Miadokova, E.; Rauko, P.; Slamenova, D.; Korolenko, T.A. Yeast cell wall polysaccharides as antioxidants and antimutagenes: Can they fight cancer. Neoplasma 2008, 5, 387-393.

131. Rutkowski, K.; Sowa, P.; Rutkowska-Talipska, J.; Sulkowski, S.; Rutkowski, R. Allergic diseases: The price of civilisational progress. Postepy Dermatol. Alergol. 2014, 31,77-83. [CrossRef]

132. Jesenak, M.; Banovcina, P.; Rennerova, Z.; Majtan, J. $\beta$-Glucans in the treatment and prevention of allergic diseases. Allergol. Immunopathol. 2012, 42, 149-156. [CrossRef]

133. Del Giudice, M.M.; Maiello, N.; Capristo, C.; Alterio, E.; Capasso, M.; Perrone, L.; Ciprandi, G. Resveratrol plus carboxymethyl$\beta$-glucan reduces nasal symptoms in children with pollen-induced allergic rhinitis. Curr. Med. Res. Opin. 2014, 30, 1931-1935. [CrossRef] [PubMed]

134. Song, H.H.; Chae, H.S.; Oh, S.R.; Lee, H.K.; Chin, Y.W. Anti-inflammatory and anti-allergic effect of Agaricus blazei extract in bone marrow-derived mast cells. Am. J. Chin. Med. 2012, 40, 1073-1084. [CrossRef] [PubMed]

135. Ku, S.K.; Kim, J.W.; Cho, H.R. Effect of $\beta$-glucan originated from Aureobasidium pullulans asthma induced by ovalbumin in mouse. Arch. Pharm. Res. 2012, 35, 1073-1081. [CrossRef] [PubMed]

136. Burg, A.R.; Quigley, L.; Jones, A.V.; O'Connor, G.M.; Boelte, K.; McVicar, D.W.; Orr, S.J. Orally administered $\beta$-glucan attenuates the Th2 response in a model of airway hypersensitivity. Springerplus 2016, 5, 815. [CrossRef]

137. Jesenak, M.; Hrubisko, M.; Majtan, J.; Rennerova, Z.; Banovcin, P. Anti-allergic effect of pleuran ( $\beta$-glucan from Pleurotus ostreatus) in children with recurrent respiratory tract infections. Phytother. Res. 2014, 28, 471-474. [CrossRef]

138. Sarinho, E.; Medeiros, D.; Schor, D.; Rego Silva, A.; Sales, V.; Motta, M.E.; Costa, A.; Azoubel, A.; Rizzo, J.A. Production of interleukin-10 in asthmatic children after beta-1-3-glucan. Allergol. Immunopathol. 2009, 37, 188-192. [CrossRef] 
139. Yamada, J.; Hamuro, J.; Hatanaka, H.; Hamabata, K.; Kinoshita, S. Alleviation of seasonal allergic symptoms with suprfine ß-1,3-glucan: A randomized study. J. Allergy Clin. Immunol. 2007, 119, 1119-1126. [CrossRef]

140. Mahmood, F.; Hetland, G.; Nentwich, I.; Mirlashari, M.R.; Ghiasvand, R.; Nissen-Meyer, L.S.H. Agaricus blazei-Based Mushroom Extract Supplementation to Birch Allergic Blood Donors: A Randomized Clinical Trial. Nutrients 2019, 11, 2339. [CrossRef]

141. Xie, Q.M.; Deng, J.F.; Deng, Y.M.; Shao, C.S.; Zhang, H.; Ke, C.K. Effects of Cryptoporus polysaccharide on rat allergic rhinitis associated with inhibitory exotoxin mRNA expression. J. Ethnopharmacol. 2006, 107, 424-430. [CrossRef]

142. Mothana, R.A.A.; Awadh Ali, N.A.; Jansen, R.; Wegner, U.; Mentel, R.; Lindequist, U. Antiviral lanostanoid triterpenes from the fungus Ganoderma pfeifferi. Fitoterapia 2003, 74, 177-180. [CrossRef]

143. Battulga, T.; Tumurbaatar, O.; Ganzorig, O.; Ishimura, T.; Kanamoto, T.; Nakashima, H.; Miyazaki, K.; Yoshida, T. Analysis of interaction between sulfated polysaccharides and HIV oligopeptides by surface plasmon resonance. Int. J. Biol. Macromol. 2019, 125, 909-914. [CrossRef]

144. Seo, D.J.; Choi, C. Antiviral Bioactive Compounds of Mushrooms and Their Antiviral Mechanisms: A Review. Viruses 2021, 13, 350. [CrossRef] [PubMed]

145. Hetland, G.; Johnson, E.; Eide, D.M.; Grinde, B.; Samuelsen, A.B.; Wiker, H. Antimicrobial effects of $\beta$-glucans and pectin and of the Agaricus blazei-based mushroom extract, andosan ${ }^{\mathrm{TM}}$ examples of mouse models for pneumococcal-, fecal bacterial-, and mycobacterial infections. In Microbial Pathogens and Strategies for Combating Them: Science, Technology and Education; Mendez-Vilas, A., Ed.; Formatex: Badajoz, Spain, 2013; pp. 889-898.

146. Özcan, Ö.; Ertan, F. Beta-glucan Content, Antioxidant and Antimicrobial Activities of Some Edible Mushroom Species. Food Sci. Technol. 2018, 6, 47-55. [CrossRef]

147. Liang, J.; Melican, D.; Cafro, L.; Palace, G.; Fisette, L.; Armstrong, R.; Patchen, M.L. Enhanced clearance of a multiple antibiotic resistant Staphylococcus aureus in rats treated with PGG-glucan is associated with increased leukocyte counts and increased neutrophil oxidative burst activity. Int. J. Immunopharmacol. 1998, 20, 595-614. [CrossRef]

148. Persson Waller, K.; Grönlund, U.; Johannisson, A. Intramammary infusion of beta1,3-glucan for prevention and treatment of Staphylococcus aureus mastitis. J. Vet. Med. B Infect. Dis. Vet. Public Health 2003, 50, 121-127. [CrossRef]

149. Markova, N.; Kussovski, V.; Drandarska, I.; Nikolaeva, S.; Georgieva, N.; Radoucheva, T. Protective activity of lentinan in experimental tuberculosis. Int. Immunopharmacol. 2003, 3, 1557-1562. [CrossRef]

150. Chang, C.S.; Huang, S.L.; Chen, S.; Chen, S.N. Innate immune responses and efficacy of using mushrooms beta-glucan mixture (MBG) on orange-spotted grouper. Epinephelus coioides, aquaculture. Fish Shellfish. Immunol. 2013, 35, 115-125. [CrossRef] [PubMed]

151. El-Boshy, M.E.; El-Ashram, A.M.; Abdelhamid, F.M.; Gadalla, H.A. Immunomodulatory effect of dietary Saccharomyces cerevisiae, beta-glucan and laminaran in mercuric chloride treated Nile tilapia (Oreochromis niloticus) and experimentally infected with Aeromonas hydrophila. Fish Shellfish Immunol. 2010, 28, 802-808. [CrossRef] [PubMed]

152. Vetvicka, V.; Vetvickova, J. Glucan supplementation enhances the immune response against an influenza challenge in mice. Ann. Transl. Med. 2015, 3, 22. [CrossRef]

153. Gordon, M.; Bihari, B.; Goosby, E.; Gorter, R.; Greco, M.; Guralnik, M.; Mimura, T.; Rudnicki, V.; Wong, R.; Kaneko, Y. A placebo controlled trail of the immune modulator, lentinan, in HIV-positive patients: A phase I/II trial. J. Med. 1998, 29, 305-330.

154. Adotey, G.; Quarco, A.; Holliday, J.C.; Fofie, S.; Saaka, B. Effect of immunomodulating and antiviral agent of medicinal mushrooms (immune Assist 24/7 TM ) on CD+ T-lymphocyte counts of HIV-infected patents. Int. J. Med. Mushrooms 2011, 13, 109-113. [CrossRef] [PubMed]

155. Gu, C.Q.; Li, J.W.; Chao, F.; Jin, M.; Wang, X.W.; Shen, Z.Q. Isolation, identification and function of a novel anti-HSV-1 protein from Grifola frondosa. Antiviral Res. 2007, 75, 250-257. [CrossRef] [PubMed]

156. Rouhier, P.; Kopp, M.; Begot, V.; Bruneteau, M.; Fritig, B. Structural features of fungal $\beta$-d-glucans for the efficient inhibition of the initiation of virus infection on Nicotiana tabacum. Phytochemistry 1995, 39, 57-62. [CrossRef]

157. Wang, J.; Wang, H.Y.; Xia, X.M.; Li, P.; Wang, K.Y. Inhibitory effect of sulfated lentinan and lentinan against tobacco mosaic virus (TMV) in tobacco seedlings. Int. J. Biol. Macromol. 2013, 61, 264-269. [CrossRef] [PubMed]

158. Rincão, V.P.; Yamamoto, K.A.; Ricardo, N.M.P.S.; Soares, S.A.; Meirelles, L.D.P.; Nozawa, C.; Linhares, R.E.C. Polysaccharide and extracts from Lentinula edodes: Structural features and antiviral activity. Virol. J. 2012, 9, 37. [CrossRef]

159. Nguyen, T.L.; Chen, J.; Hu, Y.; Wang, D.; Fan, Y.; Wang, J.; Abula, S.; Zhang, J.; Qin, T.; Chen, X.; et al. In vitro antiviral activity of sulfated Auricularia auricula polysaccharides. Carbohydr. Polym. 2012, 90, 1254-1258. [CrossRef]

160. Fan, X.; Hu, H.; Chen, D.; Yu, B.; He, J.; Yu, J.; Luo, J.; Eckhardt, E.; Luo, Y.; Wang, J.; et al. Lentinan administration alleviates diarrhea of rotavirus-infected weaned pigs via regulating intestinal immunity. J. Anim. Sci. Biotechnol. 2021, 12, 43. [CrossRef] [PubMed]

161. Alves, M.J.; Ferreira, I.C.F.R.; Dias, J.; Teixeira, V.; Martins, A.; Pintado, M. A review on antifungal activity of mushroom (Basidiomycetes) extracts and isolated compounds. Curr. Top. Med. Chem. 2013, 13, 2648-2659. [CrossRef]

162. Waithaka, P.N.; Gathuru, E.M.; Githaiga, B.M.; Onkoba, K.M. Antimicrobial Activity of Mushroom (Agaricus bisporus) and Fungal (Trametes gibbosa) Extracts from Mushrooms and Fungi of Egerton Main Campus, Njoro Kenya. J. Biomed. Sci. 2017, 6, 3. [CrossRef]

163. Merel, D.; Savoie, J.M.; Mata, G.; Salmones, D.; Ortega, C.; Atanasova, V.; Chéreau, S.; Monribot-Villanueva, J.L.; Guerrero-Analco, J.A. Methanolic Extracts from Cultivated Mushrooms Affect the Production of Fumonisins B and Fusaric Acid by Fusarium verticillioides. Toxins 2020, 12, 366. [CrossRef] [PubMed] 
164. Minari, M.C.; Rincão, V.P.; Soares, S.A.; Ricardo, N.M.; Nozawa, C.; Linhares, R.E. Antiviral properties of polysaccharides from Agaricus brasiliensis in the replication of bovine herpesvirus 1. Acta Virol. 2011, 55, 255-259. [CrossRef]

165. Drummond, R.A.; Brown, G.D. The role of Dectin -1 in the host defence against fungal infections. Curr. Opin. Microbiol. 2011, 14, 392-399. [CrossRef]

166. Roeder, A.; Kirschning, C.J.; Rupec, R.A.; Schaller, M.; Weindl, G.; Korting, H.C. Toll-like receptors as key mediators in innate antifungal immunity. Med. Mycol. 2004, 42, 485-498. [CrossRef] [PubMed]

167. Zhang, W.; Zhao, Y.; Zhang, F.; Wang, Q.; Li, T.; Liu, Z.; Wang, J.; Qin, Y.; Zhang, X.; Yan, X.; et al. The use of anti-inflammatory drugs in the treatment of people with severe coronavirus disease 2019 (COVID-19): The Perspectives of clinical immunologists from China. Clin. Immunol. 2020, 214, 108393. [CrossRef] [PubMed]

168. Rao, K.S.; Suryaprakash, V.; Senthilkumar, R.; Preethy, S.; Katoh, S.; Ikewaki, N.; Abraham, S.J.K. Role of Immune Dysregulation in Increased Mortality Among a Specific Subset of COVID-19 Patients and Immune-Enhancement Strategies for Combatting Through Nutritional Supplements. Front. Immunol. 2020, 11, 1548. [CrossRef]

169. Huang, C.; Wang, Y.; Li, X.; Ren, L.; Zhao, J.; Hu, Y.; Zhang, L.; Fan, G.; Xu, J.; Gu, X.; et al. Clinical features of patients infected with 2019 novel coronavirus in Wuhan, China. Lancet 2020, 395, 497-506. [CrossRef]

170. van Steenwijk, H.P.; Bast, A.; de Boer, A. Immunomodulating Effects of Fungal Beta-Glucans: From Traditional Use to Medicine. Nutrients 2021, 13, 1333. [CrossRef]

171. Netea, M.G.; Joosten, L.A.B.; Latz, E.; Mills, K.H.G.; Natoli, G.; Stunnenberg, H.G.; O’Neill, L.A.J.; Xavier, R.J. Trained immunity: A program of innate immune memory in health and disease. Science 2016, 352, aaf1098. [CrossRef]

172. Geller, A.; Yan, J. Could the Induction of Trained Immunity by $\beta$-Glucan Serve as a Defense against COVID-19? Front. Immunol. 2020, 11, 1782. [CrossRef]

173. dos Santos, J.C.; Barroso de Figueiredo, A.M.; Teodoro Silva, M.V.; Cirovic, B.; de Bree, L.C.J.; Damen, M.S.M.A.; Moorlag, S.J.C.F.M.; Gomes, R.S.; Helsen, M.M.; Oosting, M.; et al. $\beta$-Glucan-Induced Trained Immunity Protects against Leishmania braziliensis Infection: A Crucial Role for IL-32. Cell Rep. 2019, 28, 2659-2672.e6. [CrossRef]

174. Leonhardt, J.; Große, S.; Marx, C.; Siwczak, F.; Stengel, S.; Bruns, T.; Bauer, R.; Kiehntopf, M.; Williams, D.L.; Wang, Z.Q.; et al. Candida albicans $\beta$-Glucan Differentiates Human Monocytes into a Specific Subset of Macrophages. Front. Immunol. 2018, 9, 2818. [CrossRef]

175. Wang, X.; Ha, D.; Yoshitake, R.; Chen, S. White button mushroom interrupts tissue AR-mediated TMPRSS2 expression and attenuates pro-inflammatory cytokines in C57BL/6 mice. NPJ Sci. Food 2021, 5, 20. [CrossRef] [PubMed]

176. Han, B.; Baruah, K.; Cox, E.; Vanrompay, D.; Bossier, P. Structure-Functional Activity Relationship of $\beta$-Glucans from the Perspective of Immunomodulation: A Mini-Review. Front. Immunol. 2020, 11, 658. [CrossRef]

177. Jawhara, S. How to boost the immune defence prior to respiratory virus infections with the special focus on coronavirus infections. Gut Pathog. 2020, 12, 47. [CrossRef] [PubMed]

178. Murphy, E.J.; Rezoagli, E.; Major, I.; Rowan, N.J.; Laffey, J.G. $\beta$-Glucan Metabolic and Immunomodulatory Properties and Potential for Clinical Application. J. Fungi 2020, 6, 356. [CrossRef]

179. Ikewaki, N.; Iwasaki, M.; Kurosawa, G.; Rao, K.S.; Lakey-Beitia, J.; Preethy, S.; Abraham, S.J.K. $\beta$-Glucans: Wide-spectrum immune-balancing food-supplement-based enteric ( $\beta$-WIFE) vaccine adjuvant approach to COVID-19. Hum. Vaccines Immunother. 2021, 17, 2808-2813. [CrossRef]

180. Ikewaki, N.; Iwasaki, M.; Abraham, S.J.K. Biological response modifier glucan through balancing of blood glucose may have a prophylactic potential in COVID-19 patients. J. Diabetes Metab. Disord. 2020, 19, 1-4. [CrossRef] [PubMed]

181. Ikewaki, N.; Rao, K.S.; Archibold, A.D.; Iwasaki, M.; Senthilkumar, R.; Preethy, S.; Katoh, S.; Abraham, S.J.K. Coagulopathy associated with COVID-19-Perspectives and Preventive strategies using a biological response modifier Glucan. Thromb. J. 2020, 18, 27. [CrossRef]

182. Ikewaki, N.; Fujii, N.; Onaka, T.; Ikewaki, S.; Inoko, H. Immunological actions of Sophy beta-glucan (beta-1,3-1,6 glucan), currently available commercially as a health food supplement. Microbiol. Immunol. 2007, 51, 861-873. [CrossRef]

183. Shah, V.B.; Williams, D.L.; Keshvara, L. Beta-glucan attenuates TLR2- and TLR4-mediated cytokine production by microglia. Neurosci. Lett. 2009, 458, 111-115. [CrossRef]

184. Raghavan, K.; Kandaswamy, R.S.; Ikewaki, N.; Iwasaki, M.; Abrahame, S.J.K. Potentials to alleviate coagulopathy and enhance microglial function of beta ( $\beta$ )-glucans, making them worth a clinical study for COVID-19's neurological sequalae. J. Neurol. Sci. 2021, 427, 117554. [CrossRef] [PubMed]

185. Baldwin, K.T.; Carbajal, K.S.; Segal, B.M.; Giger, R.J. Neuroinflammation triggered by $\beta$-glucan/dectin-1 signaling enables CNS axon regeneration. Proc. Natl. Acad. Sci. USA 2015, 112, 2581-2586. [CrossRef]

186. Di Pierro, F.; Bertuccioli, A.; Cavecchia, I. Possible therapeutic role of a highly standardized mixture of active compounds derived from cultured Lentinula edodes mycelia (AHCC) in patients infected with 2019 novel coronavirus. Minerva Gastroenterol. Dietol. 2020, 66, 172-176. [CrossRef]

187. Sevindik, M. Mushrooms as natural antiviral sources and supplements foods against coronavirus (COVID-19). J Bacteriol. Mycol. Open Access 2021, 9, 73-76. [CrossRef]

188. Mallakpour, S.; Azadi, E.; Hussain, C.M. Chitosan, alginate, hyaluronic acid, gums, and $\beta$-glucan as potent adjuvants and vaccine delivery systems for viral threats including SARS-CoV-2: A review. Int. J. Biol. Macromol. 2021, 182, 1931-1940. [CrossRef] [PubMed] 
189. Soares, E.; Groothuismink, Z.M.A.; Boonstra, A.; Borges, O. Glucan particles are a powerful adjuvant for the HBsAg, favoring antiviral immunity. Mol. Pharm. 2019, 16, 1971-1981. [CrossRef]

190. Jin, J.W.; Tang, S.Q.; Rong, M.Z.; Zhang, M.Q. Synergistic effect of dual targeting vaccine adjuvant with aminated $\beta$-glucan and CpG-oligodeoxynucleotides for both humoral and cellular immune responses. Acta Biomater. 2018, 78, 211-223. [CrossRef]

191. Vancraeyneste, H.; Charlet, R.; Guerardel, Y.; Choteau, L.; Bauters, A.; Tardivel, M.; François, N.; Dubuquoy, L.; Soloviev, D.; Poulain, D.; et al. Short fungal fractions of beta-1,3 glucans affect platelet activation. Am. J. Physiol. Heart Circ. Physiol. 2016, 3113, H725-H734. [CrossRef] [PubMed]

192. Aida, F.M.N.A.; Shuhaimi, M.; Yazid, M.; Maaruf, A.G. Mushrooms as a potential source of prebiotics: A review. Trend. Food Sci. Technol. 2009, 20, 567-575. [CrossRef]

193. Yang, S.; Xie, X.; Ma, J.; He, X.; Li, Y.; Du, M.; Li, L.; Yang, L.; Wu, Q.; Chen, W.; et al. Selective Isolation of Bifidobacterium from Human Faeces Using Pangenomics, Metagenomics, and Enzymology. Front. Microbiol. 2021, 12, 649698. [CrossRef] [PubMed]

194. Mitsou, E.K.; Saxami, G.; Stamoulou, E.; Kerezoudi, E.; Terzi, E.; Koutrotsios, G.; Bekiaris, G.; Zervakis, G.I.; Mountzouris, K.C.; Pletsa, V.; et al. Effects of Rich in B-Glucans Edible Mushrooms on Aging Gut Microbiota Characteristics: An In Vitro Study. Molecules 2020, 25, 2806. [CrossRef] [PubMed]

195. Nikitina, O.; Cherno, N.; Osolina, S.; Naumenko, K. Yeast glucan and glucan-containing mushroom biopolymer complexesStimulators of microflora growth. Int. Food Res. J. 2017, 24, 2220-2227.

196. Zhao, R.; Yang, W.; Pei, F.; Zhao, L.; Hu, Q. In vitro fermentation of six kinds of edible mushrooms and its effects on fecal microbiota composition. LWT-Food Sci. Technol. 2018, 96, 627-635. [CrossRef]

197. Vamanu, E.; Gatea, F.; Sârbu, I. In Vitro Ecological Response of the Human Gut Microbiome to Bioactive Extracts from Edible Wild Mushrooms. Molecules 2018, 23, 2128. [CrossRef] [PubMed]

198. Nie, Y.; Lin, Q.; Luo, F. Effects of Non-Starch Polysaccharides on Inflammatory Bowel Disease. Int. J. Mol. Sci. 2017, 18, 1372. [CrossRef]

199. Gurung, M.; Li, Z.; You, H.; Rodrigues, R.; Jump, D.B.; Morgun, A.; Shulzhenko, N. Role of gut microbiota in type 2 diabetes pathophysiology. EBioMedicine 2020, 51, 102590. [CrossRef]

200. Guo, W.L.; Pan, Y.Y.; Li, L.; Li, T.T.; Liu, B.; Lv, X.C. Ethanol extract of Ganoderma lucidum ameliorates lipid metabolic disorders and modulates the gut microbiota composition in high-fat diet fed rats. Food Funct. 2018, 9, 3419-3431. [CrossRef]

201. Diling, C.; Yinrui, G.; Longkai, Q.; Xiaocui, T.; Yadi, L.; Jiaxin, F.; Xiangxiang, Z.; Miao, Z.; Ou, S.; Dongdong, W.; et al. Metabolic regulation of Ganoderma lucidum extracts in high sugar and fat diet-induced obese mice by regulating the gut-brain axis. $J$. Funct. Foods 2020, 65, 103639. [CrossRef]

202. Li, M.; Yu, L.; Zhao, J.; Zhang, H.; Chen, W.; Zhai, Q.; Tian, F. Role of dietary edible mushrooms in the modulation of gut microbiota. J. Funct. Foods 2021, 83, 104538. [CrossRef]

203. Ruthes, A.C.; Cantu-Jungles, T.M.; Cordeiro, L.M.C.; Iacomini, M. Prebiotic potential of mushroom d-glucans: Implications of physicochemical properties and structural features. Carbohydr. Polym. 2021, 262, 117940. [CrossRef]

204. Muthukumaran, J.; Xiao, J.; Xu, B.A. Critical Review on Health Promoting Benefits of Edible Mushrooms through Gut Microbiota. Int. J. Mol. Sci. 2017, 18, 1934. [CrossRef] 